\title{
The influence of leaf photosynthetic efficiency and stomatal closure on canopy carbon uptake and evapotranspiration - a model study in wheat and sugar beet
}

\author{
A. Schickling ${ }^{1,2}$, A. Graf $^{4}$, R. Pieruschka ${ }^{3}$, C. Plückers ${ }^{3}$, H. Geiß ${ }^{2}$, I.-L. Lai ${ }^{3}$, \\ J. H. Schween ${ }^{1}$, K. Erentok ${ }^{3}$, M. Schmidt ${ }^{5}$, A. Wahner ${ }^{2}$, S. Crewell ${ }^{1}$, and \\ U. Rascher ${ }^{3}$ \\ ${ }^{1}$ Institute of Geophysics and Meteorology, University of Cologne, Köln, Germany \\ ${ }^{2}$ Institute of Chemistry and Dynamics of the Geosphere, ICG-2: Troposphere, \\ Forschungszentrum Jülich $\mathrm{GmbH}$, Jülich, Germany \\ ${ }^{3}$ Institute of Chemistry and Dynamics of the Geosphere, ICG-3: Phytosphere, \\ Forschungszentrum Jülich $\mathrm{GmbH}$, Jülich, Germany \\ ${ }^{4}$ Institute of Chemistry and Dynamics of the Geosphere, ICG-4: Agrosphere, \\ Forschungszentrum Jülich $\mathrm{GmbH}$, Jülich, Germany \\ ${ }^{5}$ Department of Geography, University of Cologne, Köln, Germany
}

The influence of leaf photosynthetic efficiency and stomatal closure

A. Schickling et al.

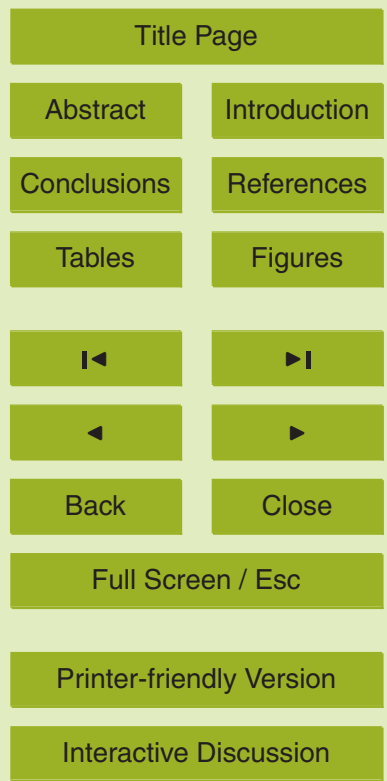


Received: 23 August 2010 - Accepted: 26 August 2010 - Published: 24 September 2010 Correspondence to: A. Schickling (a.schickling@fz-juelich.de)

Published by Copernicus Publications on behalf of the European Geosciences Union.

BGD

$7,7131-7172,2010$

The influence of leaf photosynthetic efficiency and stomatal closure

A. Schickling et al.

Title Page

Abstract Introduction

Conclusions References

Tables Figures

14 $\rightarrow 1$

4

Back

Close

Full Screen / Esc

Printer-friendly Version

Interactive Discussion 


\section{Abstract}

In this study two crop species, winter wheat (Triticum aestivum) and sugar beet (Beta vulgaris), were monitored over the course of five days during the entire season. We investigated the link of the main physiological leaf-level mechanisms, stomatal con5 ductance and efficiency of photosynthetic energy conversion on canopy transpiration and photosynthetic $\mathrm{CO}_{2}$ uptake. The physiological status of 900 leaves of different plants in a natural canopy was characterized on the leaf level using chlorophyll fluorescence. Gas exchange measurements were performed at leaves of 12 individual plants of each species. Eddy covariance flux measurements provided information on $10 \mathrm{CO}_{2}$, water and energy fluxes on the field scale. The diurnal pattern of stomatal resistance on the leaf level was especially for sugar beet similar to the canopy resistance, which indicates that stomatal resistance may have a large impact on the bulk canopy resistance. The diurnal changes in canopy resistance appeared to have less effect on the evapotranspiration, which was mainly dependent on the amount of incoming 15 radiation. The similar diurnal pattern of water use efficiency on the leaf level and on the canopy level during the day, underline the influence of physiological mechanisms of leaves on the canopy. The greatest difference between water use efficiency on leaf and canopy occurred in the morning, mainly due to an increase of stomatal resistance. Limitation of $\mathrm{CO}_{2}$ uptake occurred in the afternoon when water vapor pressure deficit increased. Maxima of net ecosystem productivity corresponded to the highest values of photosynthetic capacity of single leaves, which occurred before solar noon. Within the course of a few hours, photosynthetic efficiency and stomatal resistance of leaves varied and these variations were the reason for diurnal variations in the carbon fluxes of the whole field. During the seasonal development, the leaf area index was the main factor driving carbon and water exchange, when both crops were still growing. During senescence of winter wheat these structural parameters did not account for changes in canopy fluxes and remaining high green leaf material of sugar beet did not present the reduction in canopy fluxes due to beginning dormancy. We thus hypothesize that the

\section{The influence of leaf photosynthetic efficiency and stomatal closure}

A. Schickling et al.

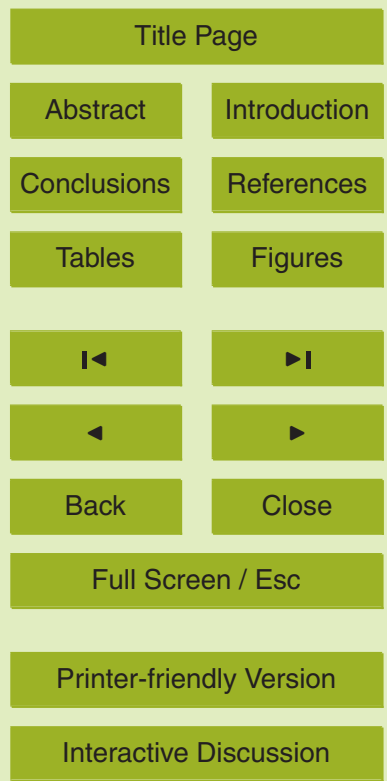


functional status of plants is also important to correctly predict carbon and water fluxes throughout the season. We propose to additionally include the physiological status of plants in carbon flux models in order to improve the quality of the simulation of diurnal patterns of carbon fluxes.

\section{Introduction}

Photosynthesis is the dominant process determining carbon dioxide $\left(\mathrm{CO}_{2}\right)$ and water vapor $\left(\mathrm{H}_{2} \mathrm{O}\right)$ fluxes between the terrestrial biogeosphere and the atmosphere. The physiology of a plant adapts dynamically to fast changes of environmental conditions such as light, temperature and water vapor pressure deficit of the air. Stomatal conduc10 tance and the efficiency of photosynthetic energy conversion are the main physiological control mechanisms. They are influenced by intrinsic and extrinsic stimuli and interactively regulate the rate of transpiration and photosynthetic $\mathrm{CO}_{2}$ uptake (Farquhar and Sharkey, 1982; Willmer and Fricker, 1996). In general, photosynthetic $\mathrm{CO}_{2}$ uptake is limited from its theoretical maximum and depends on availability of resources, mainly 15 water and nitrogen when no disease or pest are involved. Environmental factors which influence plant performance are greatly variable on various time scales, ranging from seconds to seasons. Thus, photosynthesis almost never operates at a steady state, but continuously adapts to changing environmental conditions like light, temperature and changes in humidity (Rascher and Nedbal, 2006; Schurr et al., 2006).

Photosynthesis is commonly characterized in single leaf measurements to derive the carboxylation efficiency, which is then used to project to the ecosystem carbon fluxes (Collatz et al., 1991). However, scaling from the leaf to the canopy is challenging because of the large variability of the environment, plant and leaf properties within different patches of the ecosystem. Leaves within the canopy are exposed to rapidly changing spatio-temporal light conditions as well as gradients of meteorological parameters such as temperature and vapor pressure deficit inside and above the canopy (Arain et al., 2000; Bauerle et al., 2007; Hirose and Werger, 1987).

\section{BGD}

$7,7131-7172,2010$

The influence of leaf photosynthetic efficiency and stomatal closure

A. Schickling et al.

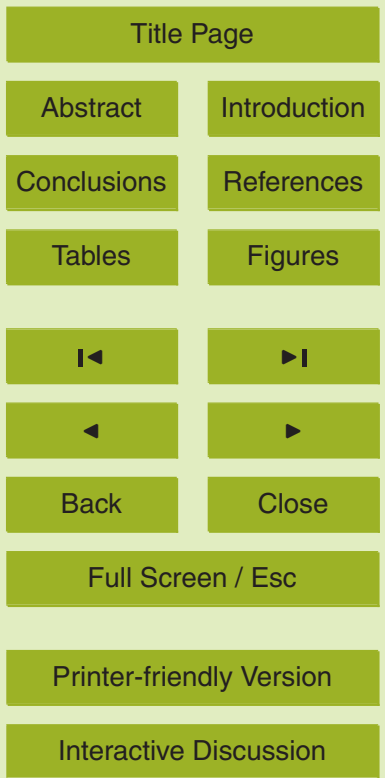


Feedback mechanisms within canopies are thought to decrease the impact of single leaves and stomata on the bulk canopy exchange of water and carbon, and it is postulated that with increasing scale the exchange processes between terrestrial vegetation and the atmosphere are increasingly driven by the atmospheric boundary layer (Jarvis 5 and McNaughton, 1986).

In many models, photosynthetic $\mathrm{CO}_{2}$ uptake and plant evapotranspiration is estimated by accounting for different levels of complexity from mechanistic soil-vegetationatmosphere transfer models (SVAT) to empirical formulations, where photosynthesis is simply modeled as a function of plant functional group, temperature and light (see 10 Cramer et al., 1999 for an overview). In the few past years, it has been recognized that ignoring the physiological responses of plant ecosystems to environmental constraints may introduce substantial uncertainties in modeling terrestrial carbon and water fluxes (Gerbig et al., 2009; Hanan et al., 2005; Sarrat et al., 2009).

Despite the importance of applying plant physiological processes from the leaf to the 15 canopy and ultimately to the ecosystem, up to now only limited data is available on the contribution of physiological processes of single leaves to canopy exchange under field conditions (Hoyaux et al., 2008). The combination of measurements on the leaf and canopy scale is mostly based on theoretical assumptions (Collatz et al., 1991). One reason for this gap might be the lack of a suitable methodology for measurements on different scales.

On the leaf level, it is possible to determine the physiological status of photosynthesis by using fluorescence measurements (Baker, 2008; Genty et al., 1989; Krause and Weis, 1991) or gas exchange measurements, which can separate the photosynthetic $\mathrm{CO}_{2}$ uptake, respiration and transpiration rate of a single leaf (Long and Bernacchi, 25 2003).

On the canopy level, eddy covariance (EC) measurements provide a powerful tool to determine $\mathrm{CO}_{2}$ and water fluxes (Baldocchi, 2003). EC is a bulk measurement of the exchange processes of the entire ecosystem and provides little constraint on the bottom-up scaling approaches. More targeted measurements of the performance
BGD

$7,7131-7172,2010$

\section{The influence of leaf photosynthetic efficiency and stomatal closure}

A. Schickling et al.

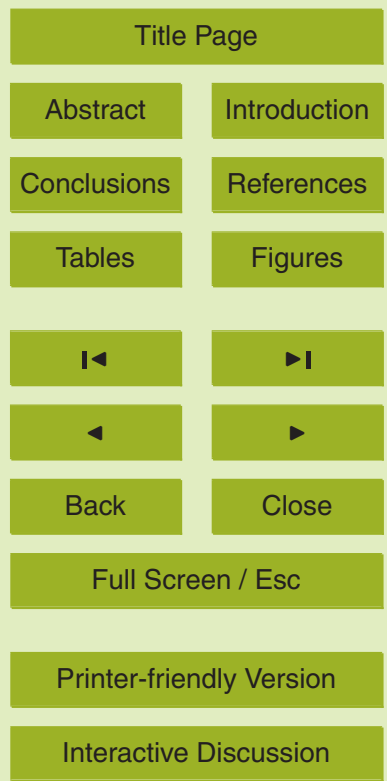


of many individual leaves in the context of their diverse natural environments in the canopy are necessary. It should be kept in mind that the total of the individuals matches the top-down constraint provided by EC measurements. Unfortunately, limited access to the leaves of many canopies and the impossibility of accurately measuring many 5 leaves under naturally fluctuating conditions put major constraints on combined leaf and canopy level measurements. Agricultural systems provide a unique opportunity to perform important field measurements. Monocropping and potential access to plant individuals provide the opportunity to compare the performance of single leaves and bulk canopies.

10 In this study, we compared the characteristics of the photosynthetic efficiency of two agricultural $\mathrm{C}_{3}$-plants, winter wheat and sugar beet, on the timescale of a day as well as seasonal changes. The detailed leaf-level characterization of the physiology of winter wheat and sugar beet was carried out in close combination with integrated $\mathrm{CO}_{2}$ and water flux measurements performed by the EC method on the canopy level. The 15 interpretation of characteristic diurnal and seasonal patterns of leaf-level gas exchange and fluorescence measurements can help to interpret the diurnal pattern of $\mathrm{CO}_{2}$ and water fluxes on the canopy scale.

\section{Materials and methods}

\subsection{Study site}

20 The measurements were embedded in the FLUXPAT campaign, an experimental study of spatio-temporal structures in atmosphere-land surface energy, water and $\mathrm{CO}_{2}$ exchange. For an overview of all measurements during the FLUXPAT field campaigns see Schween et al. (2009).

The test sites are located in a region dominated by agriculture within the Rur catch25 ment (North Rhine-Westphalia, Germany). The main crops in this area are cereals and sugar beet; rape and corn can also be found in some scattered areas. Two intensive
BGD

7, 7131-7172, 2010

\section{The influence of leaf photosynthetic efficiency and stomatal closure}

A. Schickling et al.

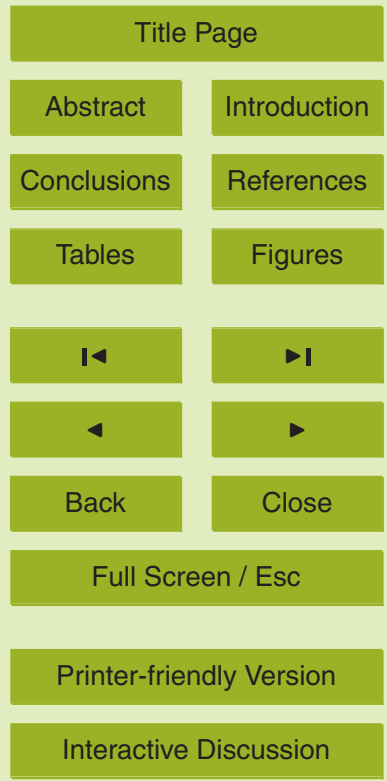


measurement fields, a winter wheat field (Triticum aestivum "Raspail") near Selhausen $\left(50^{\circ} 52^{\prime} 12.82^{\prime \prime} \mathrm{N}, 6^{\circ} 26^{\prime} 59.59^{\prime \prime} \mathrm{E}, 105 \mathrm{~m}\right.$ a.s.I.) and a sugar beet field (Beta vulgaris "Lucata") near Merken ( $50^{\circ} 50^{\prime} 46.93^{\prime \prime} \mathrm{N}, 6^{\circ} 23^{\prime} 48.99^{\prime \prime} \mathrm{E}, 114 \mathrm{~m}$ a.s.I.) were chosen for the measurements.

$5 \quad$ While the sugar beet field had a maximum altitude difference of less than $1 \mathrm{~m}$ within the field the winter wheat field crossed a gentle terrain step with an altitude difference of about $4 \mathrm{~m}$ between the lower and the higher part. This led to a marked difference in stone content (particles $>2 \mathrm{~mm}$ ) from more than $55 \%$ in the higher to less than $5 \%$ in the lower part of the fields. The texture of the soil $(<2 \mathrm{~mm})$ was silt loam at both sites o according to the USDA classification.

Winter wheat was sown at day of the year (DOY) 323 in 2007 and harvested at DOY 219 in 2008. Sugar beet was sown at DOY 112 in 2008 , later than usual because of a prolonged rainy period. The plants were harvested in October 2008. Even though sugar beet is a biannual plant it is usually harvested at the end of the first growing year. 15 Thus, sugar beet did not show any senescence or reduction of green leaf material at the time of harvest.

The core measurements were performed on five days in 2008 , which were selected by the phenological status of the crops plus preferably cloudless weather conditions. Winter wheat was measured during different growth stages in spring and summer on DOY 127 and on DOY 176. While on DOY 127 the winter wheat was in the three knops development stage (code 33 according to the $\mathrm{BBCH}$ table of Meier, 1997) on DOY 176 flower was already over and the ears were fully developed but still green $(\mathrm{BBCH}-$ scale 75). Sugar beet measurements were performed on DOY 183, DOY 229 and DOY 253. On DOY 183 more than 9 leaves of the sugar beet pant were already developed (BBCH-scale 31) and DOY229 the canopy continued to close up (BBCH-scale 33). On the last measurement day the canopy was nearly closed (BBCH-scale code 39).

On each day, the total diurnal course was measured from 07:00 to 16:00 UTC.

\section{BGD}

$7,7131-7172,2010$

\section{The influence of leaf photosynthetic efficiency and stomatal closure}

A. Schickling et al.

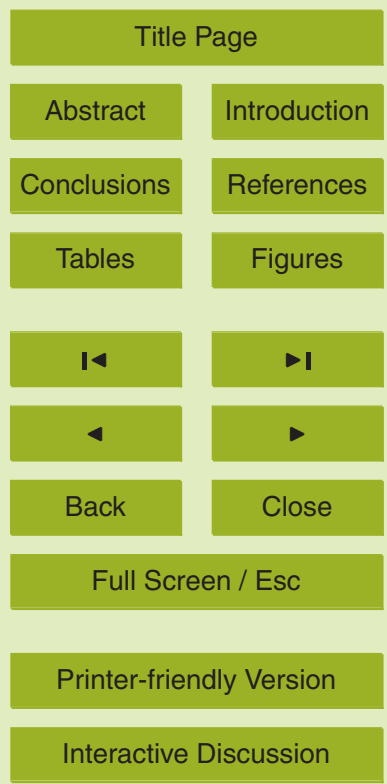




\subsection{Measurements at leaf level}

Leaf chlorophyll content of the two species was determined frequently over the whole vegetation period to give information about the development status of leaves. Leaflevel measurements of diurnal change on photosynthesis, $\mathrm{CO}_{2}$ and $\mathrm{H}_{2} \mathrm{O}$ exchange on 5 the five measurement days were performed using a pulse-amplitude-modulated (PAM) fluorometer and a gas exchange analyzer (Fig. 1).

\subsubsection{Chlorophyll content}

The leaf chlorophyll content was determined with a chlorophyll meter SPAD-502 (Spectrum Technologies Inc. Plainfield, IL, USA). By measuring the absorbance of the leaf 10 in the red and near-infrared band the amount of chlorophyll present in the leaf tissue can be deduced. Earlier measurements showed that the chlorophyll content of leaves does not change in the course of a day (data not shown). Therefore 200 SPAD measurements, randomly distributed inside the canopy, were taken once a day.

SPAD readings were calibrated for each species using laboratory analysis methods. 15 For calibration, leaf disks were cut with a cork borer and instantly stored in liquid nitrogen. Leaf pigments were later extracted and spectroscopically analyzed using the method described by Lichtenthaler (1987).

\subsubsection{Fluorescence measurements}

To characterize diurnal and seasonal changes of the light reaction of photosynthesis 20 the fluorescence signal of chlorophyll a was used. Chlorophyll fluorescence is emitted from photosynthetic active leaves in the red and near-infrared spectrum and is indirectly correlated to the energy used for photosynthesis (see Baker, 2008 for an overview).

These chlorophyll fluorescence measurements were performed on the five measurement days with the miniaturized pulse-amplitude-modulated photosynthesis yield
BGD

$7,7131-7172,2010$

The influence of leaf photosynthetic efficiency and stomatal closure

A. Schickling et al.

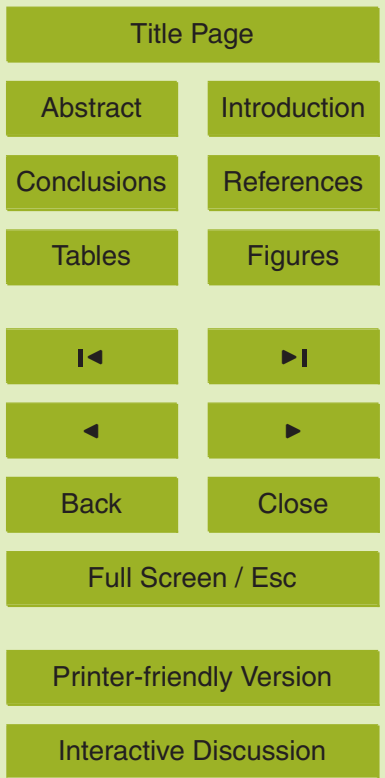


analyzer Mini-PAM (Heinz Walz GmbH, Eichenring, Effeltrich, Germany). Fluorescence was stimulated by pulsed-modulated red light from a light-emitting diode (LED).

Leaves inside the canopy were dark-adapted (> $30 \mathrm{~min}$ ) to measure the initial fluorescence $\left(F_{0}\right)$. Afterwards a saturating light pulse was applied to the leaf to determine 5 the maximum fluorescence $\left(F_{\mathrm{m}}\right)$ of dark-adapted leaves and subsequently the potential quantum yield $\left(F_{\mathrm{v}} / F_{\mathrm{m}}\right)$ of photosystem II (PS II) was determined according to

$F_{\mathrm{v}} / F_{\mathrm{m}}=\frac{F_{\mathrm{m}}-F_{0}}{F_{\mathrm{m}}}$

Healthy leaves of higher plants have $F_{\mathrm{v}} / F_{\mathrm{m}}$ values of 0.83 while significantly lower potential quantum yield values indicate damage to PS II due to photoinhibition (Björkman and Demmig, 1987).

Light-adapted measurements over leaves exposed to ambient incident photosynthetic photon flux density (PPFD) were performed with a leaf clip holder described by Bilger et al. (1995). In the course of one day 900 light adapted measurements on randomly distributed leaves inside the canopy were measured to determine the fluorescence yield $(F)$ at ambient light conditions, taking special care not to change the ambient conditions, e.g. the angle of the leaf or shading. To determine maximum fluorescence $\left(F_{\mathrm{m}^{\prime}}\right)$, a saturating pulse was superimposed on ambient light conditions. The effective quantum yield $\left(\Delta F / F_{\mathrm{m}^{\prime}}\right)$ of the light reaction of PS II was measured after Genty et al. (1989) according to

$\Delta F / F_{\mathrm{m}^{\prime}}=\frac{F_{\mathrm{m}^{\prime}}-F}{F_{\mathrm{m}}}$.

The photosynthetic electron transport rate (ETR) was derived from the fluorescence measurements as

$\mathrm{ETR}=\Delta F / F_{\mathrm{m}^{\prime}} \cdot \mathrm{PPFD} \cdot 0.5 \cdot 0.84$,

the factor 0.5 assumes equal excitation of both PS II and PS I; 0.84 accounts for the standard ETR-Factor defining the fraction of incident light estimated to be absorbed by the sample.
BGD

7, 7131-7172, 2010

The influence of leaf photosynthetic efficiency and stomatal closure

A. Schickling et al.

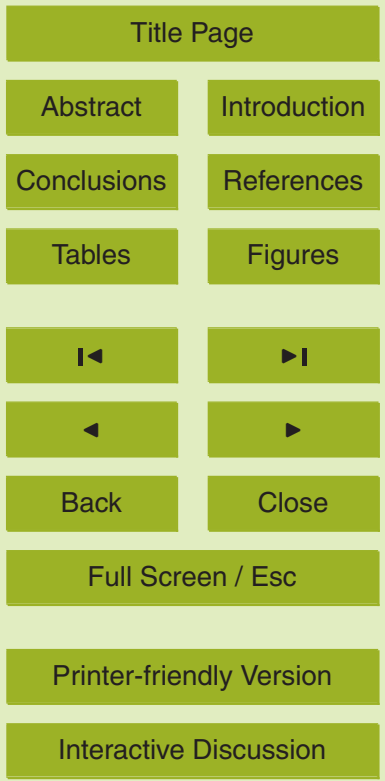


Thus, ETR can be interpreted as the amount of exited chlorophyll electrons that are used for photochemistry. Non-photochemical quenching (NPQ) was calculated as after Bilger and Björkman (1990) according to

$\mathrm{NPQ}=\frac{F_{\mathrm{m}^{\prime}}-F_{\mathrm{m}}}{F_{\mathrm{m}^{\prime}}}$.

5 NPQ mechanisms protect the photosynthetic apparatus from photo-oxidative damage by degrading excess energy into heat.

\subsubsection{Gas exchange measurements}

Leaf-level gas exchange was measured using the LI-6400 (LiCor, Lincoln, NE, USA). This is an open measurement system, where air flow was moved through a controlled 10 atmosphere surrounding a plant leaf enclosed in an assimilation chamber. The $\mathrm{CO}_{2}$ and $\mathrm{H}_{2} \mathrm{O}$ exchange was then measured with infrared gas absorbance. The $\mathrm{CO}_{2}$ level of the air was maintained in a steady state at $390 \mathrm{ppm}$. The light response curves of the net $\mathrm{CO}_{2}$ assimilation rate $(A)$ and transpiration rate (Tr) were measured using the LED light source LI-6400-02B (LiCor, Lincoln, NE, USA). Radiation was set to 2000, 1000, $15500,200,100,50,20,10 \mu \mathrm{mol} \mathrm{m}^{-2} \mathrm{~s}^{-1}$ and dark. Air humidity and temperature inside the measuring chamber were adjusted to ambient conditions. Since the determination of a light response curve took approximately $45 \mathrm{~min}$, up to twelve measurements on individual plants were performed from 07:00 to 16:00 UTC on each observation day. On DOY 127 the fully developed leaf from the upper layer at this development stage was taken to perform gas exchange measurements. On DOY 176 lower layers already started to be senescent, thus, the flag leaf was used for the measurements. For sugar beet mature leaves were available on all days and gas-exchange measurements were performed on randomly selected mature leaves of the external ring of the sugar beet rosette.

\section{BGD}

7, 7131-7172, 2010

The influence of leaf photosynthetic efficiency and stomatal closure

A. Schickling et al.

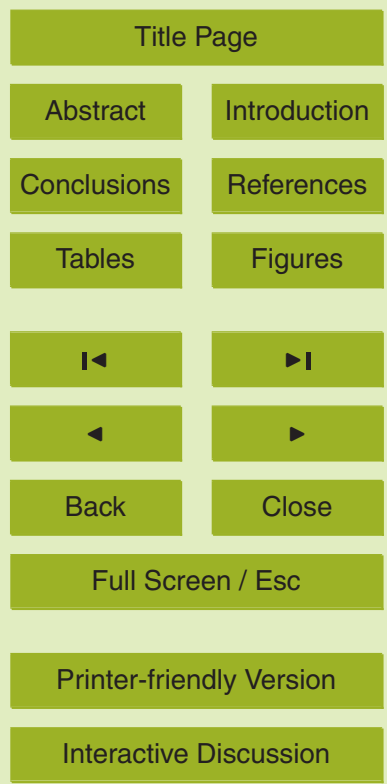




\subsection{Integrating leaf-level measurements to the canopy scale}

Characterization of structural parameters was performed in a two weeks frequency over the whole vegetation period to obtain information about the development status of the plant canopy. Leaf-level measurements carried out with PAM fluorometry were used

5 to achieve characteristic plant parameters, which represent the physiological plasticity of a species. Light curves of the gas exchange measurements allowed the estimation of maximum photosynthetic parameters to characterize the potential photosynthetic performance at saturating light intensity (Fig. 1).

\subsubsection{Leaf area index and canopy height}

10 The leaf area index ( $\mathrm{LAl})$ is the total one-sided area of leaf tissue per unit ground surface area. It is a key parameter in ecophysiology and in studies of plant growth. A destructive method was used to derive the LAl. Three spots were sampled for each field. At each spot the canopy height was measured three times. Afterwards for each spot the leaves of two rows of winter wheat, with a length of $60 \mathrm{~cm}$, and three plants 15 of sugar beet were harvested. The leaf area of the harvested leaf material was determined with a LI 3000A area meter (LiCor, Lincoln, NE, USA). Green and yellow leaf materials were treated separately. The LAI $\left[\mathrm{m}^{2} \mathrm{~m}^{-2}\right]$ was determined taking into account the row distance of winter wheat and plant closeness for sugar beet.

\subsubsection{Maximum electron transport rate and non-photochemical quenching parameter at saturating light intensity}

Additional information on characteristic plant parameters of a species, which are not related to the momentary ambient light conditions, but rather to the ontogeny of a leaf and to the range of physiological plasticity of a plant, can be derived from light response curves. Therefore all ETR versus PPFD values of a $1.5 \mathrm{~h}$ window $(n=150)$ were fitted

with an single exponential rise to maximum function

\section{BGD}

7, 7131-7172, 2010

The influence of leaf photosynthetic efficiency and stomatal closure

A. Schickling et al.

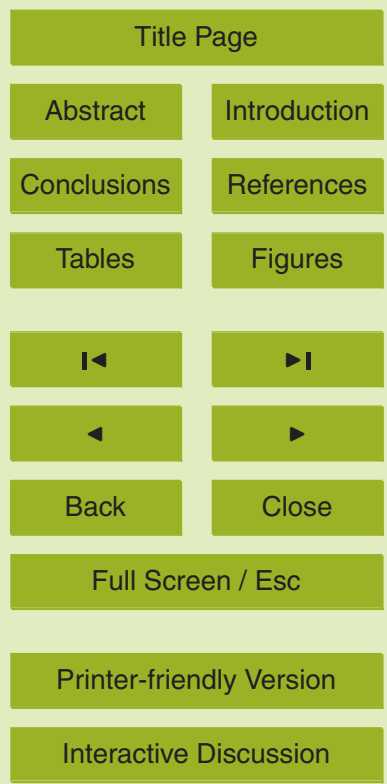


$f(x)=a \cdot\left(1-\exp ^{-b \cdot x}\right)$

in order to quantify the maximum electron transport rate $\left(a=E_{T R} R_{\max }\right)$, which is an indicator of the photosynthetic capacity of the plant canopy (Fig. 1; Rascher et al., 2000). To eliminate the dependence of light intensity on NPQ, the mean for each 1.5-h window 5 of all measured NPQ values between a PPFD of 900 and $1300 \mu \mathrm{mol} \mathrm{m}^{-2} \mathrm{~s}^{-1}$ was taken to give the non-photochemical quenching parameter at the saturating light intensity of $1100 \mu \mathrm{mol} \mathrm{m}^{-2} \mathrm{~s}^{-1}\left(\mathrm{NPQ}_{1100}\right)$. Light-adapted measurements in May could not be used because of technical difficulties.

\subsubsection{Maximum photosynthetic $\mathrm{CO}_{2}$ uptake, maximum transpiration rate and maximum stomatal resistance to water vapor pressure}

To characterize the potential photosynthetic performance of different plants during the day maximum net photosynthetic $\mathrm{CO}_{2}$ uptake rate $\left(A_{\max }\right)$ was estimated from each light response curve of gas exchange measurements (Fig. 1) using a single exponential rise to maximum function

$15 f(x)=y_{0}+a \cdot \exp ^{-b \cdot x}$.

Since the mean transpiration rate at high light intensities at $1000 \mu \mathrm{mol} \mathrm{m}^{-2} \mathrm{~s}^{-1}$ and $2000 \mu \mathrm{mol} \mathrm{m}^{-2} \mathrm{~s}^{-1}$ were not significantly different from each other but individual measurements still showed some variability, data points at $2000 \mu \mathrm{mol} \mathrm{m}{ }^{-2} \mathrm{~s}^{-1}$ were excluded from the light curve for estimating maximum transpiration rates $\left(\operatorname{Tr}_{\max }\right)$ and maximum stomatal resistance ( $\left.\mathrm{rs}_{\max }\right)$ to water vapor pressure using Eq. (6).

\subsubsection{Potential water use efficiency based on leaf-level measurements}

According to the general definition, water use efficiency is given by the ratio of net assimilation and water loss. In this study we defined the potential water use efficiency

The influence of leaf photosynthetic efficiency and stomatal closure

A. Schickling et al.

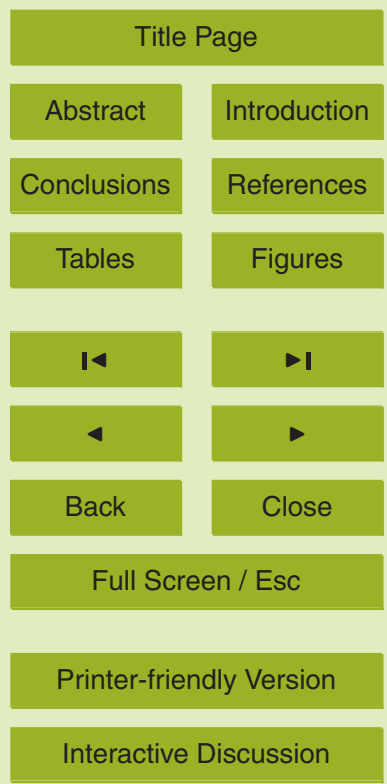


at saturated light intensities but prevailing conditions of temperature and humidity, that was derived from the leaf-level measurements (pot $W U E_{L}$ ) according to

${ }_{\text {pot }} \mathrm{WUE}_{\mathrm{L}}=\frac{A_{\max }}{\operatorname{Tr}_{\max }}$

with the maximum net photosynthetic $\mathrm{CO}_{2}$ uptake rate $\left(A_{\max }\right)$ divided by maximum 5 transpiration rate $\left(\operatorname{Tr}_{\max }\right)$.

\subsection{Measurements above the canopy}

\subsubsection{Turbulent fluxes}

A tower equipped with a CSAT3 sonic anemometer (Campbell Scientific, Inc., Logan, UT, USA) and an LI-COR 7500 open-path infrared gas analyzer for water vapor and $10 \mathrm{CO}_{2}$ (LiCor, Lincoln, NE, USA) mounted between $1.45 \mathrm{~m}$ and $2.20 \mathrm{~m}$, depending on station and measurement day, was installed on both fields to perform turbulence measurements during the whole vegetation season (Graf et al., 2010).

Additional measurements of air temperature (CS215, Campbell Scientific, Inc., Logan, UT, USA) and global radiation (SP-LITE, Kipp \& Zonen, Delft, Netherlands) were taken on the winter wheat field (Fig. 1).

Gas analyzer data were logged at a temporal resolution of $20 \mathrm{~Hz} . \mathrm{CO}_{2}$ flux (net ecosystem exchange NEE $=-$ NEP net ecosystem productivity) and evapotranspiration $(E)$, as well as its energy equivalent, the latent heat flux $(\lambda E)$, were calculated at halfhour resolution from the turbulence data by the eddy covariance method (EC). The dataset from the winter wheat field was analyzed using the TK2 software (Mauder and Foken, 2004), whereas for the sugar beet field data the ECpack software (Van Dijk, 2004) was used. Analysis of a reference data set by both software programs provided similar results. Sensible heat flux $(H)$ was corrected according to the method of Schotanus et al. (1983), the influence of density fluctuation on the other scalar fluxes according to Webb et al. (1980) and the spectral loss correction (revised after Moore,

7143
BGD

$7,7131-7172,2010$

The influence of leaf photosynthetic efficiency and stomatal closure

A. Schickling et al.

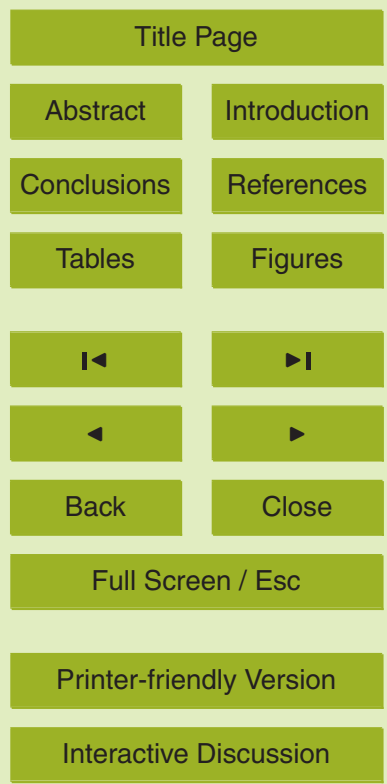


1986). For the adjustments of the vector coordinate system the double rotation method (Kaimal and Finnigan, 1994) was applied for sugar beet and the planar fit method after Wilczak et al. (2001) for winter wheat.

\subsubsection{Canopy resistance based on eddy covariance measurements}

5 Bulk canopy resistance ( $\mathrm{rc}$ ) is defined as an integrated value of the leaf stomatal resistance of a canopy. According to the "big leaf" model of Penman-Monteith, rc presents the resistance of the entire vegetation canopy to the diffusion of water vapor from leaves to the atmosphere as a result of stomatal regulation. Therefore canopy resistance was calculated using a rearranged form of the Penman-Monteith equation (Kumagai et al.,

$\mathrm{rc}=\left[\left(\frac{s}{\gamma}\right) \beta-1\right] r_{\mathrm{a}}+\frac{\rho_{\mathrm{a}} C_{\mathrm{p}}}{\gamma} \frac{\mathrm{VPD}}{\lambda E}$

where $s\left[\mathrm{~Pa} \mathrm{~K}^{-1}\right]$ is the rate of change of saturation water vapor pressure with temperature, $\gamma$ is the psychrometric constant $\left[66.5 \mathrm{~Pa} \mathrm{~K}^{-1}\right], \beta$ is the Bowen ratio $(\mathrm{H} / \lambda E), r_{\mathrm{a}}$ is the aerodynamic resistance $\left[\mathrm{m}^{-1} \mathrm{~s}\right], \rho_{\mathrm{a}}$ is the density of dry air $\left[\mathrm{kg} \mathrm{m}^{-3}\right], c_{\mathrm{p}}$ is the specific heat of air at constant pressure $\left[\mathrm{J} \mathrm{kg}^{-1} \mathrm{~K}^{-1}\right]$ and VPD $[\mathrm{kPa}]$ is the vapor pressure deficit of the air, defined as the difference of saturation water vapor pressure and water vapor pressure at current air temperature.

The aerodynamic resistance was derived by the empirical equation of Thom and Oliver (1977):

$20 \quad r_{\mathrm{a}}=\frac{4.72\left[\ln \left((z-d) / z_{0}\right)\right]^{2}}{1+0.54 u}$

where $u\left[\mathrm{~m} \mathrm{~s}^{-1}\right]$ is the wind speed at measurement height $z[\mathrm{~m}]$ (winter wheat: $1.95 \mathrm{~m}$; sugar beet: $1.45 \mathrm{~m}$ on DOY 183 and $2.20 \mathrm{~m}$ on DOY 229 and 253). The zero plane displacement $(d)[\mathrm{m}]$ and the roughness length $\left(z_{0}\right)[\mathrm{m}]$ were approximated as 0.63 and 0.13 times the vegetation height, respectively (Monteith and Unsworth, 1990).
BGD

7, 7131-7172, 2010

The influence of leaf photosynthetic efficiency and stomatal closure

A. Schickling et al.

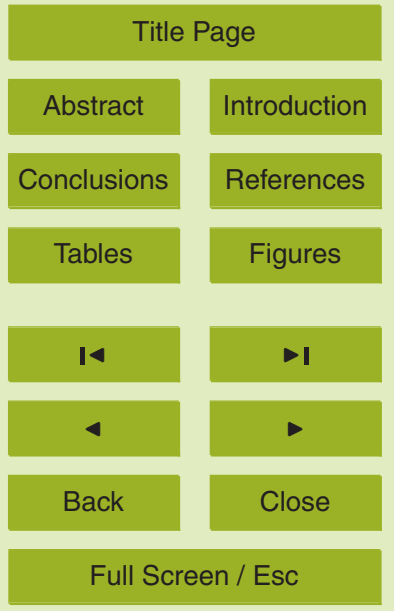

Printer-friendly Version

Interactive Discussion 


\subsubsection{Canopy water use efficiency}

Canopy scale fluxes are the joint result of gas exchange in all plant organs as well as the non-stomatal components of plant and soil evaporation, and respiration. Nevertheless, we define the ratio between the total downward $\mathrm{CO}_{2}$ and the total upward water

5 vapor flux, which thus represents the actual water use efficiency (WUE ${ }_{C}$ ) of the whole canopy-soil system:

$\mathrm{WUE}_{\mathrm{C}}=\frac{\mathrm{NEP}}{E}$

Half-hourly EC measurements were used to obtain WUE $_{\mathrm{C}}$. It was calculated by dividing the daytime net ecosystem productivity (NEP) by the corresponding evapotranspiration

$10(E)$ values (see Sect. 2.4.1).

\section{Result}

\subsection{Diurnal pattern}

In the following, we will present the general diurnal pattern of different plant physiological parameters measured on the leaf and canopy level on five intensive measurement days: DOY 127 and 176 for the winter wheat field and DOY 183, 229 and 253 for the sugar beet field.

The main focus of this study was on a qualitative comparison of the diurnal pattern between parameters measured on the leaf and canopy level. All diurnal cycles were measured on days with no (Fig. 2Ba,Ca,Ea) or only minor cloud cover (Fig. 2Aa,Da) as can be deduced from the small variation of the global radiation in the first row of Fig. 2.

For all days, VPD increased from values of $0.5 \mathrm{kPa}$ or lower to a maximum in the afternoon greater than $1.5 \mathrm{kPa}$ (Fig. $2 \mathrm{Aa}-\mathrm{Ea}$ ) and decreased in a few cases in the

\section{BGD}

7, 7131-7172, 2010

The influence of leaf photosynthetic efficiency and stomatal closure

A. Schickling et al.

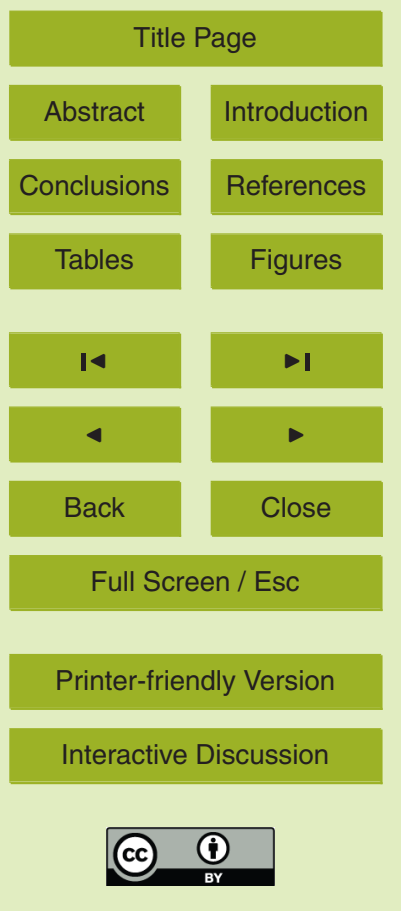


late afternoon (Fig. 2Ea), thus in part reflecting the course of the temperature with a maximum in the afternoon. Maximum leaf transpiration rates $\left(\operatorname{Tr}_{\max }\right)$ did not follow VPD, but rather showed constant values of around $2-6 \mathrm{mmol} \mathrm{m}^{-2} \mathrm{~s}^{-1}$ all day for both species (Fig. 2Ab-Eb). Canopy evapotranspiration $(E)$ reached a maximum of $56-8 \mathrm{mmol} \mathrm{m}^{-2} \mathrm{~s}^{-1}$ shortly after solar noon (11:30 UTC) on clear days (Fig. 2Bb,Cb,Eb) or the highest values of global radiation on days with few clouds (Fig. 2Ab,Db;Aa,Da). Stomatal resistance $\left(\mathrm{rs}_{\max }\right)$ at saturating light intensity on the leaf level showed no daily course for winter wheat (Fig. $2 \mathrm{Ac}, \mathrm{Bc}$ ) whereas for sugar beet $\mathrm{rs}_{\max }$ increased over the day (Fig. $2 \mathrm{Cc}-\mathrm{Ec}$ ). It should be noted that temperature in the leaf chamber of the LI10 Cor 6400 was set to match the external ambient air temperature (see Sect. 2.2.3). On DOY 127, low temperatures in the morning hours significantly affected leaf stomatal resistance, hence, $r_{\max }$ values were highest (Fig. 2Ac). Canopy resistance ( $r c$ ) of winter wheat and sugar beet was similar with rather constant values of $\mathrm{rc}$ in the morning when both evapotranspiration and VPD increased and an increase of $\mathrm{rc}$ in the after15 noon (Fig. 2Ac-Ec) when only VPD still increased. On the early morning of DOY 127 and 183 , dew led to unrealistically high values of rc. As in such cases the PenmanMontheith equation is no longer valid and as the Bowen ratio may generate a large bias, we excluded these values.

In particular for sugar beet, highest maximum electron transport rates $\left(E_{T R} R_{\text {max }}\right)$ were 20 observed in the morning before solar noon (Fig. 2Cd-Ed). The potential quantum yield of PS II of dark-adapted leaves $\left(F_{\mathrm{v}} / F_{\mathrm{m}}\right)$ for both species showed neither a significant diurnal variation nor changes in seasonal characteristics, which indicates there was no chronic or serious damage due to photoinhibition (Fig. 2Ad-Ed; Dodd et al., 1998). Maximum leaf net $\mathrm{CO}_{2}$ uptake rates $\left(A_{\max }\right)$ of winter wheat showed no distinct diurnal 25 cycle but constant values of $A_{\max }$ around $10-30 \mu \mathrm{mol} \mathrm{m}{ }^{-2} \mathrm{~s}^{-1}$ (Fig. 2Ae,Be). In contrast, values of $A_{\max }$ for sugar beet decreased over the day (Fig. 2Ce-Ee). $A_{\max }$ was found to be sensitive to stomatal resistance on the leaf level $\left(\mathrm{rs}_{\max }\right)$ with a pronounced negative correlation for both species (Table 1). On the canopy level, the net ecosystem productivity (NEP) obtained from the eddy covariance method reached maxima at solar

BGD

$7,7131-7172,2010$

\section{The influence of leaf photosynthetic efficiency and stomatal closure}

A. Schickling et al.

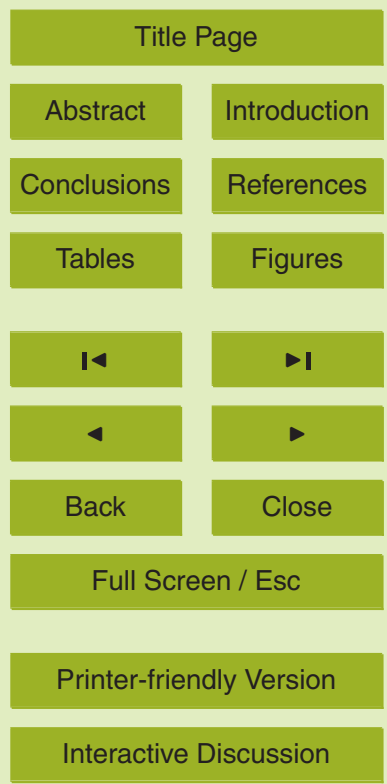


noon for winter wheat (Fig. 2Ae,Be) and before solar noon for sugar beet (Fig. 2CeEe).

For both species water use efficiency on the leaf level (pot $W U E_{L}$ ) and actual water use efficiency on the canopy level (WUE ${ }_{C}$ ) (Fig. 2Af-Ef) showed highest values in the 5 morning and decreased throughout the day. In general, values of ${ }_{\text {pot }} W_{U} E_{L}$ were higher or in the same range than WUE $E_{C}$. Only at DOY 127 one value in the morning and two ${ }_{\text {pot }} \mathrm{WUE}_{\mathrm{L}}$ values in the afternoon were slightly lower than $\mathrm{WUE}_{\mathrm{C}}$.

On the leaf level pot $W_{L} E_{L}$ was measured as the potential maximum water use efficiency under saturating light intensities inside a clip-on leaf chamber under the prevail10 ing temperature and humidity conditions. The ${ }_{\text {pot }} W_{L} E_{L}$ was higher in the morning than in the afternoon for both species (Fig. 2Af-Ef). This decrease was due to lower humidity and higher temperature in the afternoon and the increase of stomatal resistance throughout the day, especially for sugar beet. On the canopy level, values of $\mathrm{WUE}_{\mathrm{C}}$ were calculated as the ratio between the molar fluxes of water vapor and $\mathrm{CO}_{2}$ and 15 thus they are the actual water use efficiency of the canopy-soil system including the non-stomatal components of plant and soil evaporation and respiration. In the morning, photosynthesis enhanced more rapidly than evapotranspiration under increasing solar radiation and led to high $\mathrm{WUE}_{C}$ in the morning for both species (Fig. 2Af-Df). Thereafter $W_{C} E_{C}$ decreased gradually because declining photosynthesis and increasing respiration led to a decrease in NEP in the afternoon.

The feedback of VPD on stomatal resistance indicates the strong decrease of ${ }_{\text {pot }} W U E_{L}$ and influences $W U E_{C}$. The negative correlation between $V P D$, pot $W U E_{L}$ and $W_{C}$, respectively, can be described with a single exponential decay decreasing function (Fig. 3, Table 2).

25 Maximum photosynthetic electron transport rate $\left(E T R_{\max }\right)$ and non-photochemical quenching parameters at saturating light intensity $\left(N \mathrm{NQ}_{1100}\right)$ were negatively correlated and showed a dynamic adaptation of the photosynthesis in the seasonal cycle of the sugar beet crop which can be described by a linear fitting function (Fig. 4; axis interception $b=2.69$, the slope $m=-0.00578$, correlation coefficient $r=-0.93$, number

BGD

$7,7131-7172,2010$

The influence of leaf photosynthetic efficiency and stomatal closure

A. Schickling et al.

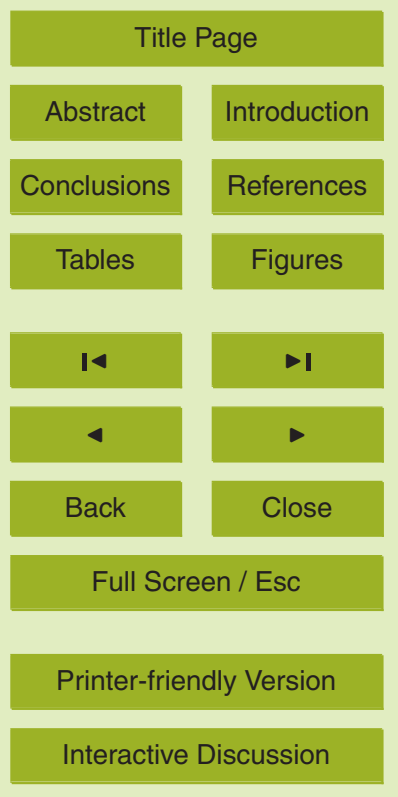


of data points $n=18$ and the significance of correlation $p$-value $<0.0001$ ).

This indicates a regulation of photosynthetic and non-photosynthetic energy conversion of light reaction throughout the season. $\mathrm{NPQ}_{1100}$ increased during the season whereas the ETR $\max$, which is indicator of photosynthetic capacity, declined. In addition 5 to the dynamics of the regulation of photosynthetic energy conversion an increase of leaf chlorophyll content during the season was detected, which indicated that changes of the physiological status of photochemistry due to beginning dormancy which was not accompanied with reduction of leaf chlorophyll content in sugar beet leaves (Fig. 4).

There was only one day with full daily coverage in winter wheat (DOY 176) which 10 showed rather low $\mathrm{NPQ}_{1100}$ values (Fig. 4). During this measurement, winter wheat had already finished flowering and grain filling was in progress. Thus the reduced non-photochemical protection with still high photosynthetic electron transport could be interpreted as a strategy to maximize carbon uptake for grain filling by reduced longterm photo-protection, which is acceptable for leaves that will soon be senescent.

\subsection{Seasonal variation}

The two crops showed differences in their development stages during the vegetation period that greatly influenced $\mathrm{CO}_{2}$ and water fluxes on leaf and canopy level during the season. After the vernalization of winter wheat, the vegetation height increased to a maximum of $80 \mathrm{~cm}$. Simultaneously, green LAI increased to a maximum of $5.5 \mathrm{~m}^{2} \mathrm{~m}^{-2}$ (DOY 136; Fig. 5a). The canopy reached maturity at the end of May (DOY 150) when flowering was already finished and grain filling began. At this time the amount of yellow leaf material increased, while green leaf material was reduced (Fig. 5a). Senescence of the wheat started at the bottom and advanced upwards to the flag leaves during the developmental stages.

25 During the growing phase of winter wheat from the beginning of March (DOY 62) to the middle of May (DOY 136), the increase of green LAI corresponded to a constant rise of $E$ and NEP (Fig. 5a,e,g). After the highest LAl had been reached, the wheat canopy still showed high photosynthetic activity (Fig. $5 \mathrm{~g}$ ) until mid June (DOY
BGD

$7,7131-7172,2010$

\section{The influence of leaf photosynthetic efficiency and stomatal closure}

A. Schickling et al.

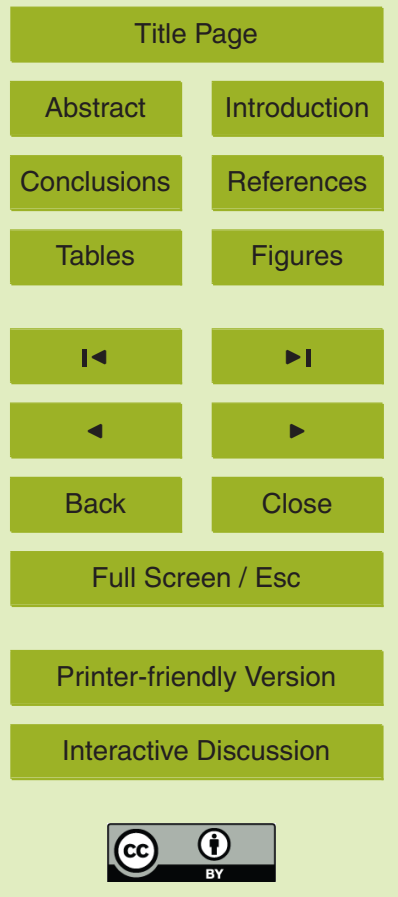


166), although yellowing already started at the lower leaves. The seasonal development of water fluxes at the winter wheat field was more variable than the $\mathrm{CO}_{2}$ flux (Fig. 5e). After harvesting in the first half of August (DOY 218), evapotranspiration still displayed values of up to $2-3 \mathrm{mmol} \mathrm{m}^{-2} \mathrm{~s}^{-1}$ due to evaporation from the soil (Fig. 5e).

5 The mean apparent maximum transpiration rate $\left(\operatorname{Tr}_{\max }\right)$ on leaf level was always lower than the canopy measurements because non-stomatal components like evaporation from soil and plants contribute to water loss of the field (Fig. 5e). The maximum net $\mathrm{CO}_{2}$ uptake rate $\left(A_{\text {max }}\right)$ of single leaves of winter wheat was lower than NEP during the growing period (DOY 127) when green LAI was up to $5.6 \mathrm{~m}^{2} \mathrm{~m}^{-2}$ (Fig. 5a) and ap10 proximately similar to NEP on DOY 176 because of the already strongly reduced green LAI ( $2 \mathrm{~m}^{2} \mathrm{~m}^{-2}$; Fig. 5a). On this measurement day only the upper leaves of the canopy which are exposed to the sunlight showed high leaf chlorophyll content and photosynthetic activity. In this case, $A_{\max }$ on the leaf level could be seen as an approximation of the NEP of the whole canopy.

15 Sugar beet was sown on DOY 112. The vegetation height of sugar beet stagnated at around $65 \mathrm{~cm}$ from DOY 200 on (Fig. 5b), but the green LAl still rose until the end of September (Fig. 5b). Since sugar beet is a biannual crop no senescence or reduction of green leaf material but dormancy can be expected at the end of summer. Sugar beet EC measurements showed large gaps during the season, because the measurements were performed with a roving station that was used on other fields between the insensitive measurement periods on this sugar beet field. Nevertheless, the development of sugar beet $E$ and NEP followed the green LAI during the growing period (Fig. 5b,f,h). Even tough LAI rose until the end of measurements the canopy $\mathrm{CO}_{2}$ and water fluxes showed a decrease towards the end of the measurement period (Fig. 5f,h). Mean daily $A_{\max }$ values were larger than NEP values while $\operatorname{Tr}_{\max }$ values were lower than $E$ (Fig. 5f,h).
BGD

7, 7131-7172, 2010

\section{The influence of leaf photosynthetic efficiency and stomatal closure}

A. Schickling et al.

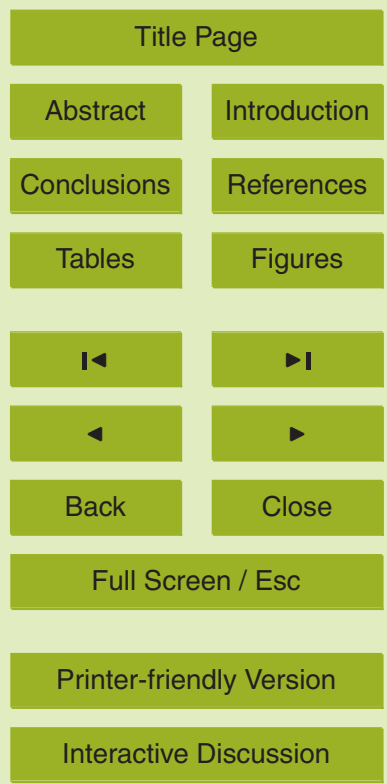




\section{Discussion}

In the present study, we investigated the structural and functional properties of two important crop species, winter wheat (Triticum aestivum) and sugar beet (Beta vulgaris), by monitoring their performance on the leaf and canopy level over the course of five 5 days and the entire season. The analysis of structural parameters allowed an evaluation of the growth status of both plant species (see Sect. 2.2), the physiological status of plants was intensively characterized on the level of leaves (see Sect. 2.3), and the entire canopy by carbon and water flux measurements with the eddy covariance method (see Sect. 2.4).

10 In our study, maximum transpiration $\left(\operatorname{Tr}_{\max }\right)$ on the leaf level was quite variable during the course of the day for both species (Fig. 2Ab-Eb). This may be due to the variability of individual plants and leaves although leaves of the same order and development stage were chosen. Stomatal resistance $\left(\mathrm{rs}_{\max }\right)$ showed no pronounced diurnal pattern for winter wheat (Fig. 2Ac,Bc). Sugar beet, however, showed an increase of $\mathrm{rs}_{\max }$ towards the afternoon when VPD increased (Fig. 2Cc-Ec). The higher sensitivity of stomatal resistance of the sugar beet leaves in contrast to winter wheat may be explained be the different construction of root distribution. Winter wheat roots can reach up to $1.5 \mathrm{~m}$ depth and are widely distributed in the soil while sugar beet roots can reach the same depth but are taproots, which are more locally attached. This may affect the water absorption and influence the sensitivity of stomatal resistance of sugar beet plants. Leaf and canopy architecture of both species is also different. Winter wheat leaves are long and narrow and are arranged in different layer. Hence most solar energy is absorbed by the upper layer of the canopy. The denseness of the canopy as well as the canopy height could cause a microenvironment with high humidity inside the canopy, which reduces the sensitivity of stomatal resistance of the winter wheat leaves. Sugar beet in contrast has larger leaves, which are in an erectophil position in the morning. Leaf inclination changes gradually through the day to a planophil position and the rosette arrangement of the leaves support an optimum supply with solar
BGD

$7,7131-7172,2010$

The influence of leaf photosynthetic efficiency and stomatal closure

A. Schickling et al.

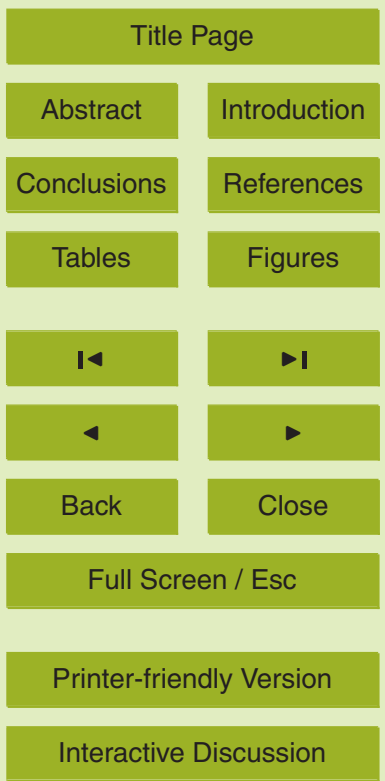


energy, already during the morning hours when sun angles are low. This might lead to a higher sensitivity of stomatal resistance of the sugar beet plant towards VPD than for winter wheat. The dependence of stomatal resistance on VPD has been discussed in numerous publications. However, Monteith (1995) reanalyzed a number of studies by 5 regarding the interaction of stomatal resistance, transpiration and VPD and concluded, as did Mott and Parkhurst (1991), that the stomata respond to the rate of transpiration rather than directly to VPD or humidity. Our results support this view and show a negative correlation for both species between $\mathrm{Tr}_{\max }$ and $\mathrm{rs}_{\max }$ (Fig. 2Ab-Eb,Ac-Ec; Table 1), but no consistent relationship between $\mathrm{rs}_{\max }$ and VPD. Sugar beet indicated 10 a positive response of $\mathrm{rs}_{\max }$ to an increasing VPD (Fig. 2Cc-Ec,Ca-Ea; Table 1), while for winter wheat (Fig. 2Ac,Aa; Table 2) no dependency or only a slightly negative but not significant response was detected (Fig. 2Bc,Ba; Table 1). Previous studies with winter wheat also showed no consistent response of stomatal resistance to VPD. While Bunce (1998) found that stomata of wheat may respond to the changes of VPD, Condon et al. 15 (1992) showed a different response of stomata to VPD, which was related to different cultivars. Inoue et al. (1989) and Rawson et al. (1977) reported no response of leaf stomatal resistance to an increase of VPD, but an increase of transpiration rate related to VPD changes as observed in the present study (DOY 176; Fig. 2Bc,Ba; Table 2).

Canopy resistance $(\mathrm{rc})$ for both species started to increase in the afternoon, when 20 VPD was already high. For winter wheat this did not correspond to $\mathrm{rs}_{\max }$ values which did not show a constant diurnal pattern (Fig. 2Ac,Bc). For sugar beet maximum stomatal resistance on the leaf level showed an increase over the day, which was also presented on canopy level by an increase of $\mathrm{rc}$ in the afternoon (Fig. 2Ac-Ec). This indicates that stomatal resistance may have a large impact on the bulk canopy resistance. On the canopy level, evapotranspiration $(E)$ showed less fluctuation than single leaf measurements. The correlation of stomatal resistance and maximum transpiration discovered on the leaf level was not presented on the canopy scale. Diurnal changes in rc appear to have less effect on the evapotranspiration since $E$ was mainly dependent on the incoming solar energy (Table 1) thus supporting previous studies that showed

\section{BGD}

$7,7131-7172,2010$

\section{The influence of leaf photosynthetic efficiency and stomatal closure}

A. Schickling et al.

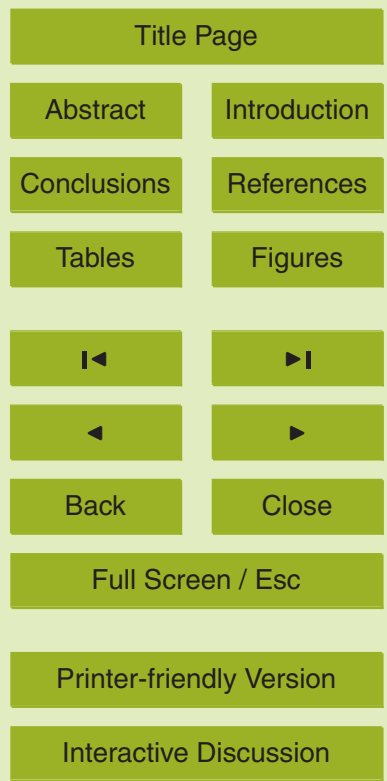


a correlation between $E$ and available energy (Dekker et al., 2000; Douglas et al., 2009; Priestley and Taylor, 1972). McNaughton and Jarvis (1991) showed that feedback mechanisms within a canopy can cause the canopy response to the environment to be more stable than an individual leaf which could explain the difference between 5 the response of $\mathrm{rs}_{\max }$ respectively rc to the transpiration

Our data also confirm a negative correlation between $\mathrm{rs}_{\max }$ and $A_{\max }$ as already described in several studies (e.g., Guo et al., 2002; Steduto et al., 1997; Fig. 2Ac-Ec; $\mathrm{Ae}-\mathrm{Ee}$ ). On DOY 127, low temperatures in the morning hours significantly affected leaf stomatal resistance, hence, $\mathrm{rs}_{\max }$ values were highest in the morning (Fig. 2Ac). This 10 influenced the correlation between $\mathrm{rs}_{\max }$ and $A_{\max }$ leading to an extremely low slope and a poor correlation (Fig. 2; Table 1). NEP and stomatal resistance on the canopy level were also negatively correlated.

Maximum values of NEP were reached at solar noon for winter wheat (Fig. 2Ae,Be) and before solar noon for sugar beet (Fig. 2Ce-Ee). Thus, sugar beet did not respond 15 to the highest incoming radiation (Fig. 2Ca-Ea; Ce-Ee). A previous study by Pingintha et al. (2010) in a peanut canopy stated that up to $89 \%$ of daytime NEE variations are primarily controlled by the incoming radiation. Since canopy resistance usually started to increase around noon the reduced canopy $\mathrm{CO}_{2}$ uptake in the afternoon might also be related to progressive stomatal closure and therefore diffusional limitations of $\mathrm{CO}_{2}$ 20 (Fig. 2Cc-Ec). Additionally, the maximum electron transport rate $\left(\mathrm{ETR}_{\max }\right)$ showed highest values in the morning hours before solar noon, which corresponded to NEP maxima, especially for sugar beet (Fig. 2Cd-Ed). Thus, the efficiency of photosynthetic light reactions was not constant during the day, but followed a pattern with the highest values in the photosynthetic capacity of sugar beet in the morning, which also influences the diurnal pattern of canopy $\mathrm{CO}_{2}$ uptake. While other studies, e.g., Flexas

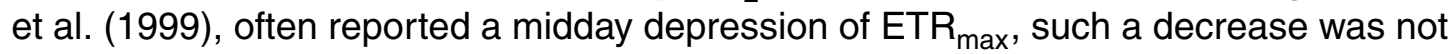
observed in the present study, which points to well-irrigated conditions of the studies crops during the whole season.

BGD

$7,7131-7172,2010$

The influence of leaf photosynthetic efficiency and stomatal closure

A. Schickling et al.

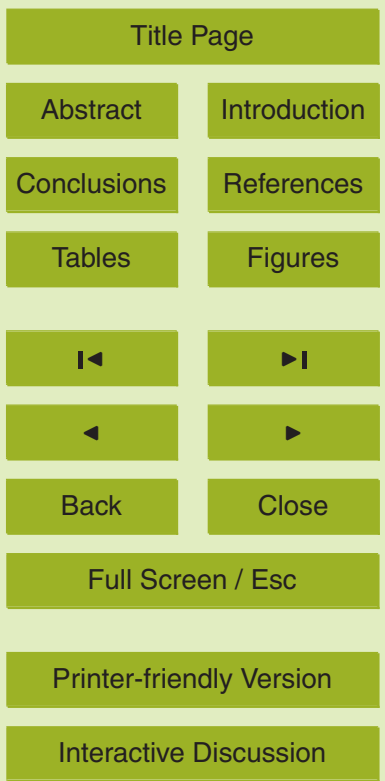


Since the crops were well watered carbon uptake could, theoretically, be maximized if stomatal resistance and thus canopy resistance were reduced in the afternoon. However, this strategy would result in a large and uncontrolled loss of water. The studied crops showed highest WUE in the morning. The potential water use efficiency on the 5 leaf level (pot $W U E_{L}$ ) and actual water use efficiency on the canopy level (WUE ${ }_{C}$ ) were highest before solar noon (Fig. 2Af-Ef) when the evaporative demand was lowest and rather high light intensities stimulate photosynthesis. The diurnal pattern of WUE was similar to other reports on cropland (Baldocchi, 1994; Tong et al., 2009) and forest (Scanlon and Albertson, 2004). Increasing evaporative demand caused stomatal re10 sistance to increase. Stomatal control is generally thought to facilitate an optimum between $\mathrm{CO}_{2}$ uptake and water loss (Farquhar and Sharkey, 1982). In agreement with previous studies, in general the ${ }_{\text {pot }} W \mathrm{E}_{\mathrm{L}}$ was higher than $\mathrm{WUE}_{\mathrm{C}}$ (Steduto et al., 1997; Tong et al., 2009). While pot $W_{L} E_{L}$ depends mainly on stomatal control of photosynthetic $\mathrm{CO}_{2}$ uptake and transpiration, $\mathrm{WUE}_{\mathrm{C}}$ is additionally influenced by non-stomatal 15 components like soil respiration and soil evaporation. An earlier study showed that for an LAI larger than two the influences of non-stomatal components became small (Tong et al., 2009). In our study, the largest difference between $W_{U} E_{C}$ and ${ }_{p o t} W U E_{L}$ occurred during the first hours of the day when the light intensity was lower than the light intensity inside a leaf chamber where pot $W_{\mathrm{L}} E_{\mathrm{L}}$ was measured. Additional evaporation from soil wo decrease $W E_{C}$ compared to the actual apparent average water use efficiency of all leaves in the canopy. Thus, soil fluxes could account for the difference between $W_{U} E_{C}$ and ${ }_{\text {pot }} W U E_{L}$ and not only photosynthetic exchange But the relation between $W_{C} E_{C}$ and ${ }_{\text {pot }} W U E_{L}$ changed during the course of the day, and it cannot be deduced whether the diminishing difference between $W U E_{C}$ and ${ }_{\text {pot }} W U E_{L}$ during the day reflects only an increase of stomatal resistance (underestimation of $W_{U} E_{C}$ ) or also increasing non-stomatal soil fluxes. This demonstrates once more the complexity of photosynthetic exchange processes in the whole canopy and the difficulties of scaling from the leaf to the canopy. But the similar diurnal pattern of ${ }_{\text {pot }} W_{L} E_{L}$ and $W_{C} E_{C}$ provides an indication that stomatal closure on leaf and canopy is the main process which largely
BGD

$7,7131-7172,2010$

\section{The influence of leaf photosynthetic efficiency and stomatal closure}

A. Schickling et al.

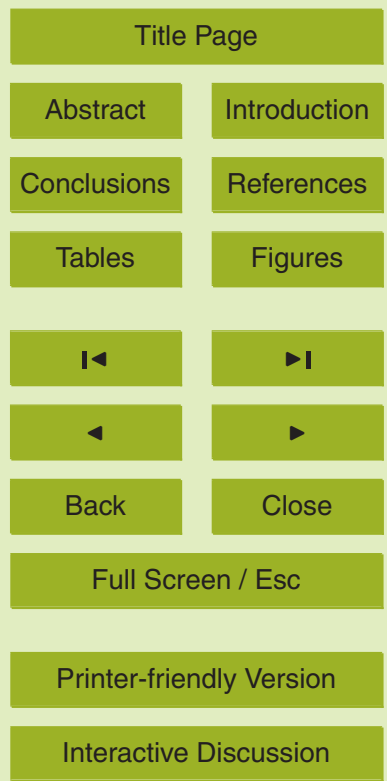


affects WUE. This is supported by the fact that a correlation of the actual canopy and potential leaf WUE with VPD was found for all measurement days. While on a seasonal base the WUE of well-watered crops depends only on VPD (Baldocchi et al., 1985), on the diurnal timescale the relationship is indicated because of an increase of stom5 atal closure in the afternoon (Baldocchi, 1994; Steduto et al., 1997). For winter wheat the pot $W_{L}$ at DOY 127 is lower than on DOY 176 which is not mirrored in $W_{C} E_{C}$ of the species. Lower values of VPD on DOY 229 led to a higher pot $W U E_{L}$ value in the morning (Fig. 3b). Slightly cloudy condition (Fig. 2Da) on this day caused higher absolute ${ }_{\text {pot }} \mathrm{WUE}_{\mathrm{L}}$ values. While $\operatorname{Tr}_{\max }$ was a comparable range to the other days $A_{\max }$ 10 values were higher resulting in higher absolute ${ }_{\text {pot }} W_{\mathrm{W}} \mathrm{E}_{\mathrm{L}}$ values. The decline on DOY 253 is generated by lower $A_{\max }$ and $\operatorname{Tr}_{\max }$ values at this time of the year due to reduced photosynthetic activity. This is also presented in the down regulation of the $\mathrm{ETR}_{\max }$ throughout the season due to beginning dormancy (Fig. 4).

Non-linearity of the correlation of VPD and actual WUE $\mathrm{C}_{\mathrm{C}}$ was due to low light con15 ditions in the morning limiting photosynthetic rate and influence actual $W U E_{C}$ values (Fig. 3c,d). While absolute values of $W_{C}$ for sugar beet do not differ significantly but range between $3 \mu \mathrm{mol} \mathrm{mmol}^{-1}$ and $11 \mathrm{mmol} \mathrm{mmol}^{-1}$ at all three measurement days (Fig. 3d). Winter wheat WUE $_{C}$ on DOY 127 was higher than on DOY 176, which is in contrast to ${ }_{p o t} W U E_{L}$. An earlier study showed that the highest $W_{U} E_{C}$ values appeared 20 at the end of April and beginning of May as the main growing phases of winter wheat (Tong et al., 2009).

Winter wheat NEP (Fig. $5 \mathrm{~g}$ ) showed similar magnitudes during the seasonal development in accordance with the results of (Anthoni et al., 2004) who monitored the carbon exchange of a winter wheat canopy in Thuringia, Germany. During the growing phase of winter wheat, an increase of green LAI and vegetation height corresponded to a rise of $E$ and NEP (Fig. 5a,e,g). After the highest green LAI was reached, the wheat canopy still showed a high photosynthetic activity during grain filling, although yellowing had already started at the lower leaves. Characterization of the photosynthetic efficiency of light reaction (Fig. 3) illustrated that the reduced non-photochemical

BGD

$7,7131-7172,2010$

The influence of leaf photosynthetic efficiency and stomatal closure

A. Schickling et al.

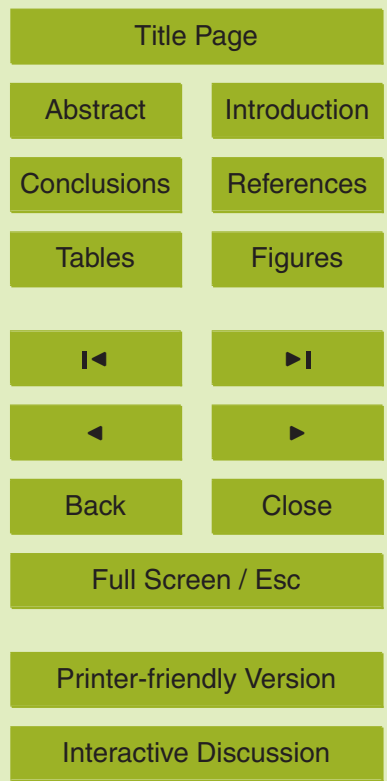


protection leading to a high maximum electron transport rate of the canopy could be interpreted as a strategy to maximize carbon uptake for grain filling. A significant reduction of NEP values of the canopy was detected during a 2-3 week period from the beginning of July (DOY 182) when green LAI dropped below $2 \mathrm{~m}^{2} \mathrm{~m}^{-2}$ and plant senes5 cence constantly reduced green leaf material until the second half of July (DOY 200) which is in accordance with similar crop studies of winter wheat in Belgium (Aubinet et al., 2009).

For sugar beet the increase of green LAI corresponded with a rise of daily $E$ and NEP (Fig. 5b,f,h). The reduction of NEP and $E$ in August and September (DOY 21310 270) did not correspond to a significant decrease in LAI (Fig. 5b), which is in line with observations by Moureaux et al. (2006). Neither leaf chlorophyll content (Fig. 3) nor leaf level measurements of potential quantum yield $\left(F_{\mathrm{v}} / F_{\mathrm{m}}\right.$; Fig. $\left.2 \mathrm{Cd}-\mathrm{Ed}\right)$ gave any indication of the senescence of sugar beet leaves. The photosynthetic capacity of the light reaction $\left(E T R_{\max }\right)$, however, decreased during the season while energy conver15 sion was balanced by increased non-photochemical quenching $\left(\mathrm{NPQ}_{1100}\right)$ parameters (Fig. 3). This reduction of photosynthetic capacity of light reaction over the season on sugar beet leaves was pronounced compared to the downward trend of leaf-level gas exchange measurements of $A_{\max }$ (Fig. 2Ce-Ee and Fig. 5h) which was previously reported in Monti et al. (2007). In our study high values of $A_{\max }$ at DOY 229 do not answer the general lower NEP values at this time a year. Seasonal development of global radiation (Fig. 5) limited the available energy for photosynthesis in August and September. Therefore the decrease of daily NEP values of the sugar beet canopy was caused by a combination of the limitation of maximum photosynthetic $\mathrm{CO}_{2}$ uptake rate on the leaf level and the concurrent reduction in solar radiance in August and September. This is supported by earlier studies where natural canopy photosynthesis did not operate at its maximum potential rate and may have been reduced under prevailing environmental conditions (Bergh et al., 1998; Rascher et al., 2004).

The photosynthetic efficiency of leaves varies largely within hours and these variations as well as changes in stomatal resistance are most likely the reason for the
BGD

7, 7131-7172, 2010

\section{The influence of leaf photosynthetic efficiency and stomatal closure}

A. Schickling et al.

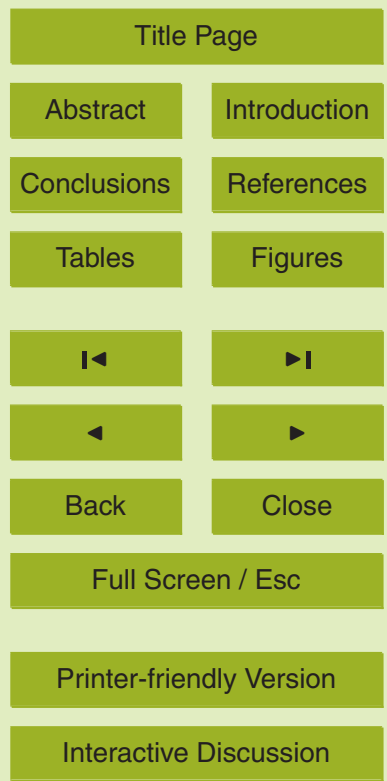


fluctuations of carbon fluxes of the whole field. On the basis of our study, we propose to additionally include the physiological status of plants in carbon flux models in order to improve the quality of the simulation of diurnal patterns of carbon fluxes and represent plant ecosystems more reliably. One way to achieve this is to use the chloro5 phyll fluorescence of photosynthetically active leaves as it was done for many years. The intensity of the re-emitted fluorescence is indirectly correlated to the energy used for photosynthesis and thus can serve as an indicator of photosynthetic light conversion (Baker, 2008). However, most fluorescence techniques rely on active excitation of leaves with saturating pulses and are therefore not applicable for remote ecosystem 10 monitoring. Modern remote sensing approaches deriving the fluorescence from hyperspectral reflectance measurement have the potential to measure the top-of-canopy fluorescence in the atmospheric oxygen absorption lines (Louis et al., 2005; Meroni et al., 2009; Rascher et al., 2009). Damm et al. (2010) showed that modeling of carbon fluxes on a timescale of one day could be improved by using the canopy fluorescence signal and this approach may become a powerful tool for better understanding the variation of photosynthetic efficiency and thus carbon uptake. However, this approach also provides some challenges since a range of different factors influence the fluorescence signal, such as canopy structural effects (LAI, chlorophyll content) and bidirectional effects (changing viewing illumination geometry), which are not completely understood 20 yet.

\section{Appendix A}

\section{Abbreviations}

[ $\left.A_{\text {max }}\right]$ maximum photosynthetic net $\mathrm{CO}_{2}$ uptake rate at saturating light intensity 25

[DOY]

\section{BGD}

$7,7131-7172,2010$

\section{The influence of leaf photosynthetic efficiency and stomatal closure}

A. Schickling et al.

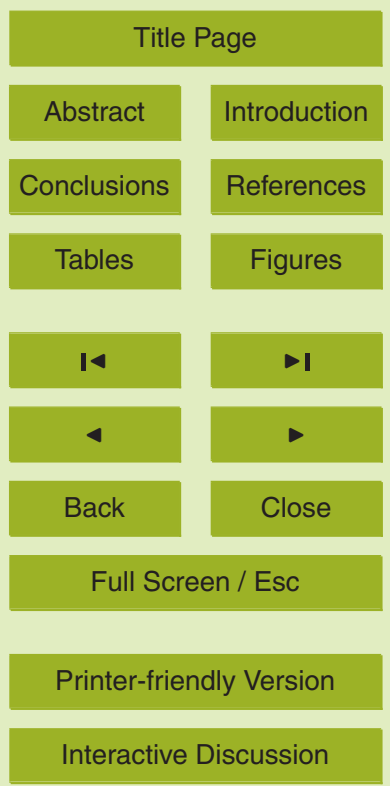


[E] evapotranspiration $\left(\mathrm{mmol} \mathrm{m}^{-2} \mathrm{~s}^{-1}\right)$

[ETR] photosynthetic electron transport rate $\left(\mu \mathrm{mol} \mathrm{m} \mathrm{m}^{-2} \mathrm{~s}^{-1}\right)$

BGD

$\left[E T R_{\max }\right]$ maximum photosynthetic electron transport rate $\left(\mu \mathrm{mol} \mathrm{m} \mathrm{m}^{-2} \mathrm{~s}^{-1}\right)$

$7,7131-7172,2010$

$[F] \quad$ fluorescence yield of light-adapted leaf (a.u.)

$5 \quad\left[F_{0}\right] \quad$ initial fluorescence at dark-adapted leaf (a.u.)

$\left[F_{\mathrm{m}}\right] \quad$ maximum fluorescence of dark-adapted leaf (a.u.)

$\left[F_{\mathrm{m}^{\prime}}\right]$ maximum fluorescence of light-adapted leaf (a.u.)

$\left[F_{\mathrm{v}}\right] \quad$ variable fluorescence of dark-adapted leaf (a.u.)

$\left[F_{\mathrm{v}} / F_{\mathrm{m}}\right]$ maximum quantum yield of PS II of dark-adapted leaf (a.u.)

$10[H]$ leaf area index $\left(\mathrm{m}^{2} \mathrm{~m}^{-2}\right)$

[LED] light-emitting diode

[NEE] net ecosystem exchange $\left(\mu \mathrm{mol} \mathrm{m}^{-2} \mathrm{~s}^{-1}\right)$

[NEP] net ecosystem productivity $\left(\mu \mathrm{mol} \mathrm{m}^{-2} \mathrm{~s}^{-1}\right)$

The influence of leaf photosynthetic efficiency and stomatal closure

A. Schickling et al.

[NPQ] non-photochemical quenching parameter

$15\left[\mathrm{NPQ}_{1100}\right]$ non-photochemical quenching parameter at saturating light intensity of $1100 \mu \mathrm{mol} \mathrm{m}^{-2} \mathrm{~s}^{-1}$

[pot $\left.W_{L} E_{L}\right]$ potential water use efficiency at saturating light intensity on leaf level scale $\left(\mu \mathrm{mol} \mathrm{mmol}{ }^{-1}\right)$

Title Page

Abstract Introduction

Conclusions

References

Tables

Figures

14

4

Back

Close

Full Screen / Esc

[PPFD] photosynthetic photon flux density $\left(\mu \mathrm{mol} \mathrm{m} \mathrm{m}^{-2} \mathrm{~s}^{-1}\right)$

Printer-friendly Version

Interactive Discussion

[rc] bulk canopy resistance $\left(\mathrm{mol}^{-1} \mathrm{~m}^{2} \mathrm{~s}^{1}\right)$ 
$\left[\mathrm{rs}_{\max }\right]$ stomatal resistance at saturating light intensity $\left(\mathrm{mol}^{-1} \mathrm{~m}^{2} \mathrm{~s}^{1}\right)$

$\left[\mathrm{Tr}_{\max }\right]$ maximum transpiration rate at saturating light intensity $\left(\mathrm{mmol} \mathrm{m}^{-2} \mathrm{~s}^{-1}\right)$

BGD

[VPD] water vapor pressure deficit of the air $(\mathrm{kPa})$

$\left[\mathrm{WUE}_{\mathrm{C}}\right]$ water use efficiency on canopy scale $\left(\mu \mathrm{mol} \mathrm{mmol}{ }^{-1}\right)$

$5[\lambda E] \quad$ latent heat flux

Acknowledgement. We gratefully acknowledge financial support provided by the SFB/TR 32 "Patterns in Soil-Vegetation-Atmosphere Systems: Monitoring, Modelling, and Data Assimilation" - subproject D2 (www.tr32.de), funded by the Deutsche Forschungsgemeinschaft (DFG). The authors wish to thank Victoria Lenz-Wiedemann, Julia Dierl, Jörn Kilzer, Nils-

10 Peter Neubauer and Eva Wieners (all University of Cologne) and Akpona Okujeni (HumboldtUniversität zu Berlin) for their valuable help during the field campaigns.

\section{References}

Anthoni, P. M., Freibauer, A., Kolle, O., and Schulze, E. D.: Winter wheat carbon exchange in Thuringia, Germany, Agr. Forest Meteorol., 121, 55-67, 2004.

Arain, M. A., Shuttleworth, W. J., Farnsworth, B., Adams, J., and Sen, O. L.: Comparing micrometeorology of rain forests in Biosphere-2 and Amazon basin, Agr. Forest Meteorol., 100, 273-289, 2000.

Aubinet, M., Moureaux, C., Bodson, B., Dufranne, D., Heinesch, B., Suleau, M., Vancutsem, F., and Vilret, A.: Carbon sequestration by a crop over a 4-year sugar beet/winter wheat/seed potato/winter wheat rotation cycle, Agr. Forest Meteorol., 149, 407-418, 2009.

Baker, N. R.: Chlorophyll fluorescence, a probe of photosynthesis in vivo, Annu. Rev. Plant Biol., 59, 89-113, 2008.

Baldocchi, D.: A comparative-study of mass and energy-exchange rates over a closed C-3 (wheat) and an open C-4 (corn) crop. 2. $\mathrm{CO}_{2}$ exchange and water-use efficiency, Agr. Forest Meteorol., 67, 291-321, 1994.

\section{The influence of leaf photosynthetic efficiency and stomatal closure}

A. Schickling et al.

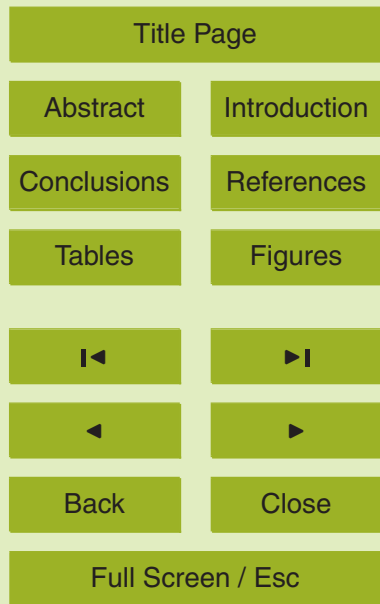

Printer-friendly Version

Interactive Discussion 
Baldocchi, D. D.: Assessing the eddy covariance technique for evaluating carbon dioxide exchange rates of ecosystems, past, present and future, Global Change Biol., 9, 479-492, 2003.

Baldocchi, D. D., Verma, S. B., and Rosenberg, N. J.: Water-use efficiency in a soybean field influence of plant water-stress, Agr. Forest Meteorol., 34(1), 53-65, 1985.

Bauerle, W. L., Bowden, J. D., and Wang, G. G.: The influence of temperature on within-canopy acclimation and variation in leaf photosynthesis, spatial acclimation to microclimate gradients among climatically divergent Acer rubrum L. genotypes, J. Exp. Bot., 58, 3285-3298, 2007.

Bergh, J., McMurtrie, R. E., and Linder, S.: Climatic factors controlling the productivity of Norway spruce, a model-based analysis, Forest Ecol. Manag., 110, 127-139, 1998.

Bilger, W. and Björkman, O.: Role of the xanthophyll cycle in photoprotection elucidated by measurements of light-induced absorbency changes, fluorescence and photosynthesis in leaves of hedera-canariensis, Photosynth. Res., 25, 173-185, 1990.

Bilger, W., Schreiber, U., and Bock, M.: Determination of the quantum efficiency of photosystem-II and of nonphotochemical quenching of chlorophyll fluorescence in the field, Oecologia, 102, 425-432, 1995.

Björkman, O. and Demmig, B.: Photon yield of O-2 evolution and chlorophyll fluorescence characteristics at 77-K among vascular plants of diverse origins, Planta, 170, 489-504, 1987.

Bunce, J. A.: Effects of humidity on short-term responses of stomatal conductance to an increase in carbon dioxide concentration, Plant Cell Environ., 21, 115-120, 1998.

Collatz, G. J., Ball, J. T., Grivet, C., and Berry, J. A.: Physiological and environmental-regulation of stomatal conductance, photosynthesis and transpiration - a model that includes a laminar boundary-layer, Agr. Forest Meteorol., 54, 107-136, 1991.

Condon, A. G., Richards, R. A., and Farquhar, G. D.: The effect of variation in soil-water availability, vapor-pressure deficit and nitrogen nutrition on carbon isotope discrimination in wheat, Aust. J. Agr. Res., 43, 935-947, 1992.

Cramer, W., Kicklighter, D. W., Bondeau, A., Moore, B., Churkina, C., Nemry, B., Ruimy, A., and Schloss, A. L.: Comparing global models of terrestrial net primary productivity (NPP), overview and key results, Global Change Biol., 5, 1-15, 1999.

30 Damm, A., Elbers, J., Erler, A., Gioli, B., Hamdi, K., Hutjes, R., Kosvancova, M., Meroni, M., Miglietta, F., Moersch, A., Moreno, J., Schickling, A., Sonnenschein, R., Udelhoven, T., Van der Linden, S., Hostert, P., and Rascher, U.: Remote sensing of sun-induced fluorescence to improve modeling of diurnal courses of gross primary production (GPP), Global Change
BGD

$7,7131-7172,2010$

\section{The influence of leaf photosynthetic efficiency and stomatal closure}

A. Schickling et al.

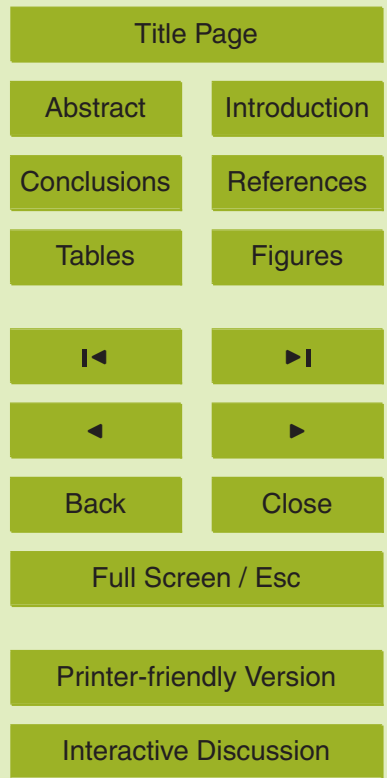


Biol., 16, 171-186, 2010.

Dekker, S. C., Bouten, W., and Verstraten, J. M.: Modelling forest transpiration from different perspectives, Hydrol. Process., 14, 251-260, 2000.

Dodd, I. C., Critchley, C., Woodall, G. S., and Stewart, G. R.: Photoinhibition in differently coloured juvenile leaves of Syzygium species, J. Exp. Bot., 49, 1437-1445, 1998

Douglas, E. M., Jacobs, J. M., Sumner, D. M., and Ray, R. L.: A comparison of models for estimating potential evapotranspiration for Florida land cover types, J. Hydrol., 373, 366376, 2009.

Farquhar, G. D. and Sharkey, T. D.: Stomatal conductance and photosynthesis, Annu. Rev. Plant Phys., 33, 317-345, 1982.

Flexas, J., Escalona, J. M., and Medrano, H.: Water stress induces different levels of photosynthesis and electron transport rate regulation in grapevines, Plant Cell Environ., 22, 39-48, 1999.

Genty, B., Briantais, J. M., and Baker, N. R.: The relationship between the quantum yield of pho15 tosynthetic electron-transport and quenching of chlorophyll fluorescence, Biochim. Biophys. Acta, 990, 87-92, 1989.

Gerbig, C., Dolman, A. J., and Heimann, M.: On observational and modelling strategies targeted at regional carbon exchange over continents, Biogeosciences, 6, 1949-1959, doi:10.5194/bg-6-1949-2009, 2009.

20 Graf, A., Schüttemeyer, D., Geiss, H., Knaps, A., Mollmann-Coers, M., Schween, J. H., Kollet, S., Neininger, B., Herbst, M., and Vereecken, H.: Boundedness of turbulent temperature probability distributions, and their relation to the vertical profile in the convective boundary layer, Bound.-Lay. Meteorol., 134, 459-486, 2010.

Guo, J. M., Jermyn, W. A., and Turnbull, M. H.: Diurnal and seasonal photosynthesis in two 25 asparagus cultivars with contrasting yield, Crop Sci., 42, 399-405, 2002.

Hanan, N. P., Berry, J. A., Verma, S. B., Walter-Shea, E. A., Suyker, A. E., Burba, G. G., and Denning, A. S.: Testing a model of $\mathrm{CO}_{2}$, water and energy exchange in Great Plains tallgrass prairie and wheat ecosystems, Agr. Forest Meteorol., 131, 162-179, 2005.

Hirose, T. and Werger, M. J. A.: Maximizing daily canopy photosynthesis with respect to the leaf nitrogen allocation pattern in the canopy, Oecologia, 72, 520-526, 1987.

Hoyaux, J., Moureaux, C., Tourneur, D., Bodson, B., and Aubinet, M.: Extrapolating gross primary productivity from leaf to canopy scale in a winter wheat crop, Agr. Forest Meteorol., 148, 668-679, 2008.
BGD

$7,7131-7172,2010$

The influence of leaf photosynthetic efficiency and stomatal closure

A. Schickling et al.

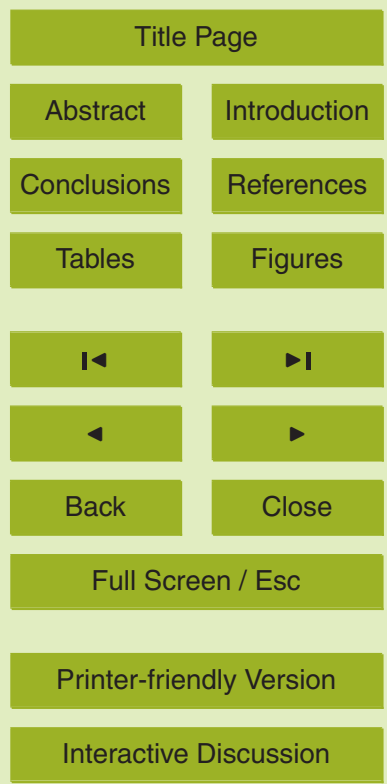


Inoue, Y., Jackson, R. D., Pinter, P. J., and Reginato, R. J.: Influences of extractable soil-water and vapor-pressure deficit on transpiration and stomatal-resistance in differentially irrigated wheat, Jpn. J. Crop Sci., 58, 430-437, 1989.

Jarvis, P. G. and McNaughton, K. G.: Stomatal control of transpiration, scaling up from leaf to region, Adv. Ecol. Res., 15, 1-49, 1986.

Kaimal, J. C. and Finnigan, J. J.: Atmospheric boundary layer flows, their structure and measurements, Oxford University Press, New York, 304 pp., 1994.

Krause, G. H. and Weis, E.: Chlorophyll fluorescence and photosynthesis - the basics, Annu. Rev. Plant Physiol., 42, 313-349, 1991.

10 Kumagai, T., Saitoh, T. M., Sato, Y., Morooka, T., Manfroi, O. J., Kuraji, K., and Suzuki, M.: Transpiration, canopy conductance and the decoupling coefficient of a lowland mixed dipterocarp forest in Sarawak, Borneo, dry spell effects, J. Hydrol., 287, 237-251, 2004.

Lichtenthaler, H. K.: Chlorophylls and carotenoids - pigments of photosynthetic biomembranes, Method. Enzymol., 148, 350-382, 1987.

Long, S. P. and Bernacchi, C. J.: Gas exchange measurements, what can they tell us about the underlying limitations to photosynthesis? Procedures and sources of error, J. Exp. Bot., 54, 2393-2401, 2003.

Louis, J., Ounis, A., Ducruet, J. M., Evain, S., Laurila, T., Thum, T., Aurela, M., Wingsle, G., Alonso, L., Pedros, R., and Moya, I.: Remote sensing of sunlight-induced chlorophyll fluorescence and reflectance of Scots pine in the boreal forest during spring recovery, Remote Sens. Environ., 96, 37-48, 2005.

Mauder, M. and Foken, T.: Documentation and instruction manual of eddy covariance software package TK2, Department of Micrometeorology, University of Bayreuth, 2004.

McNaughton, K. G. and Jarvis, P. G.: Effects of spatial scale on stomatal control of transpiration, $25 \quad$ Agr. Forest Meteorol., 54, 276-302, 1991.

Meier, U.: BBCH-Monograph. Growth stages of plants - Entwicklungsstadien von Pflanzen Estadios de las plantas - Développement des Plantes, Berlin, 165 pp., 2001.

Meroni, M., Rossini, M., Guanter, L., Alonso, L., Rascher, U., Colombo, R. and Moreno, J.: Remote sensing of solar-induced chlorophyll fluorescence, review of methods and applications,

$30 \quad$ Remote Sens. Environ., 113, 2037-2051, 2009.

Monteith, J. L.: A reinterpretation of stomatal responses to humidity, Plant Cell Environ., 18, 357-364, 1995.

BGD

$7,7131-7172,2010$

\section{The influence of leaf photosynthetic efficiency and stomatal closure}

A. Schickling et al.

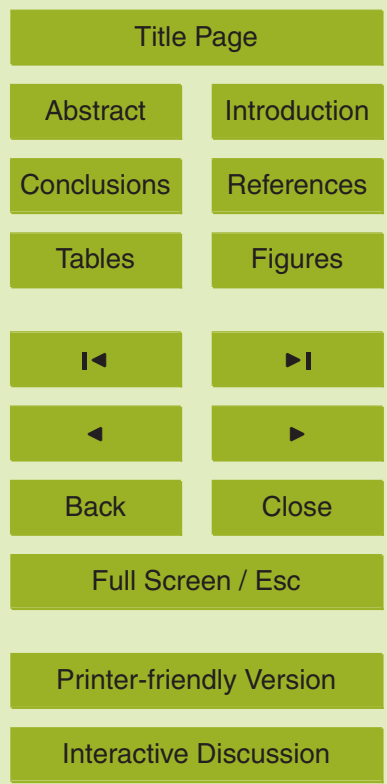


Monteith, J. L. and Unsworth, M. H.: Principles of Environmental Physics. Edward Arnold, London, 291 p., 1990.

Monti, A., Barbanti, L., and Venturi, G.: Photosynthesis on individual leaves of sugar beet (Beta vulgaris) during the ontogeny at variable water regimes, Ann. Appl. Biol., 151, 155-165, 52007.

Moore, C. J.: Frequency response corrections for eddy correlation systems, Bound.-Lay. Meteorol., 37, 17-35, 1986.

Mott, K. A. and Parkhurst, D. F.: Stomatal response to humidity in air and helox, Plant Cell Environ., 14, 509-515, 1991.

10 Moureaux, C., Debacq, A., Bodson, B., Heinesch, B., and Aubinet, M.: Annual net ecosystem carbon exchange by a sugar beet crop, Agr. Forest Meteorol., 139, 25-39, 2006.

Pingintha, N., Leclerc, M. Y., Beasley Jr., J. P., Durden, D., Zhang, G., Senthong, C., and Rowland, D.: Hysteresis response of daytime net ecosystem exchange during drought, Biogeosciences, 7, 1159-1170, doi:10.5194/bg-7-1159-2010, 2010.

15 Priestley, C. H. B. and Taylor, R. J.: Assessment of surface heat-flux and evaporation using large-scale parameters, Mon. Weather Rev., 100, 81-92, 1972.

Rascher, U., Agati, G., Alonso, L., Cecchi, G., Champagne, S., Colombo, R., Damm, A., Daumard, F., de Miguel, E., Fernandez, G., Franch, B., Franke, J., Gerbig, C., Gioli, B., Gómez, J. A., Goulas, Y., Guanter, L., Gutiérrez-de-la-Cámara, Ó., Hamdi, K., Hostert, P., Jiménez, M., Kosvancova, M., Lognoli, D., Meroni, M., Miglietta, F., Moersch, A., Moreno, J., Moya, I., Neininger, B., Okujeni, A., Ounis, A., Palombi, L., Raimondi, V., Schickling, A., Sobrino, J. A., Stellmes, M., Toci, G., Toscano, P., Udelhoven, T., van der Linden, S., and Zaldei, A.: CEFLES2: the remote sensing component to quantify photosynthetic efficiency from the leaf to the region by measuring sun-induced fluorescence in the oxygen absorption bands,

25 Biogeosciences, 6, 1181-1198, doi:10.5194/bg-6-1181-2009, 2009.

Rascher, U., Bobich, E. G., Lin, G. H., Walter, A., Morris, T., Naumann, M., Nichol, C. J., Pierce, D., Bil, K., Kudeyarov, V., and Berry, J. A.: Functional diversity of photosynthesis during drought in a model tropical rainforest - the contributions of leaf area, photosynthetic electron transport and stomatal conductance to reduction in net ecosystem carbon exchange,

30 Plant Cell Environ., 27, 1239-1256, 2004.

Rascher, U., Liebig, M., and Lüttge, U.: Evaluation of instant light-response curves of chlorophyll fluorescence parameters obtained with a portable chlorophyll fluorometer on site in the field, Plant Cell Environ., 23, 1397-1405, 2000.

BGD

$7,7131-7172,2010$

\section{The influence of leaf photosynthetic efficiency and stomatal closure}

A. Schickling et al.

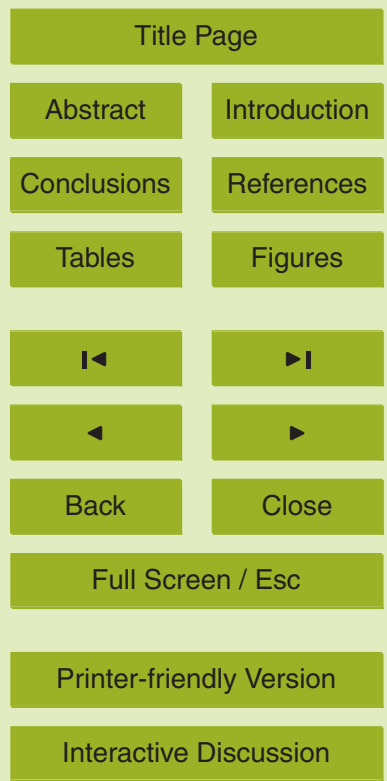


Rascher, U. and Nedbal, L.: Dynamics of photosynthesis in fluctuating light - commentary, Curr. Opin. Plant Biol., 9, 671-678, 2006.

Rawson, H. M., Begg, J. E., and Woodward, R. G.: Effect of atmospheric humidity on photosynthesis, transpiration and water-use efficiency of leaves of several plant species, Planta, 134, 5-10, 1977.

Sarrat, C., Noilhan, J., Lacarrère, P., Ceschia, E., Ciais, P., Dolman, A. J., Elbers, J. A., Gerbig, C., Gioli, B., Lauvaux, T., Miglietta, F., Neininger, B., Ramonet, M., Vellinga, O., and Bonnefond, J. M.: Mesoscale modelling of the $\mathrm{CO}_{2}$ interactions between the surface and the atmosphere applied to the April 2007 CERES field experiment, Biogeosciences, 6, 633-646,

10 doi:10.5194/bg-6-633-2009, 2009.

Scanlon, T. M. and Albertson, J. D.: Canopy scale measurements of $\mathrm{CO}_{2}$ and water vapor exchange along a precipitation gradient in southern Africa, Global Change Biol., 10, 329341, 2004.

Schotanus, P., Nieuwstadt, F. T. M., and Debruin, H. A. R.: Temperature-measurement with 15 a sonic anemometer and its application to heat and moisture fluxes, Bound.-Lay. Meteorol., 26, 81-93, 1983.

Schurr, U., Walter, A., and Rascher, U.: Functional dynamics of plant growth and photosynthesis - from steady-state to dynamics - from homogeneity to heterogeneity, Plant Cell Environ., 29, 340-352, 2006.

20 Schween, J. H., Geiß, H., Graf, A., Rascher, U., Schickling, A., Schüttemeyer, D. Neininger, B., Selbach, C., and Crewell, S.: The FLUXPAT experiment, Integrative characterization of patterns in the atmospheric boundary layer, submitted to Vadose Zone J., 2009.

Steduto, P., Katerji, N., PuertosMolina, H., Unlu, M., Mastrorilli, M., and Rana, G.: Water-use efficiency of sweet sorghum under water stress conditions gas-exchange investigations at leaf and canopy scales, Field Crop. Res., 54, 221-234, 1997.

Thom, A. S. and Oliver, H. R.: Penman's Equation for estimating regional evaporation, Q. J. Roy. Meteor. Soc., 103, 345-357, 1977.

Tong, X. J., Li, J., Yu, Q., and Qin, Z.: Ecosystem water use efficiency in an irrigated cropland in the North China Plain, J. Hydrol., 374, 329-337, 2009.

so Van Dijk, A., Moene, A. F., and De Bruin, H. A. R.: The principles of surface flux physics, theory, practice and description of the ECPACK library Internal Report 2004/1, Meteorology and Air Quality Group, Wageningen University, Wageningen, 2004.

BGD

$7,7131-7172,2010$

The influence of leaf photosynthetic efficiency and stomatal closure

A. Schickling et al.

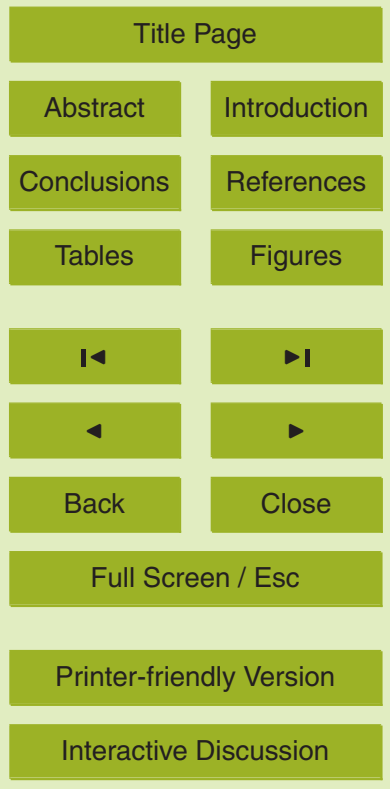


Webb, E. K., Pearman, G. I., and Leuning, R.: Correction of flux measurements for density effects due to heat and water-vapor transfer, Q. J. Roy. Meteor. Soc., 106, 85-100, 1980.

Wilczak, J. M., Oncley, S. P., and Stage, S. A.: Sonic anemometer tilt correction algorithms, Bound.-Lay. Meteorol., 99, 127-150, 2001.

5 Willmer, C. and Fricker, M.: Stomata, Chapman and Hall, London, 375 pp., 1996.

BGD

$7,7131-7172,2010$

The influence of leaf photosynthetic efficiency and stomatal closure

A. Schickling et al.

Title Page

Abstract Introduction

Conclusions References

Tables Figures

14

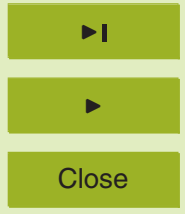

Back

Full Screen / Esc

Printer-friendly Version

Interactive Discussion 
Table 1. Statistic parameters characterizing the relationship between $\mathrm{rs}_{\max }$ and $\mathrm{Tr}_{\max }$, VPD and $\mathrm{rs}_{\max }, \mathrm{rs}_{\max }$ and $A_{\max }$ at leaf level as well as $\mathrm{Rg}$ and $E$ at canopy level. Given is the axis interception $b$, the slope $m$ of the linear fitting line the correlation coefficient $r$, the number of data points $n$ and the significance of correlation $p$-value.

\begin{tabular}{|c|c|c|c|c|c|}
\hline \multicolumn{6}{|c|}{ Leaf level } \\
\hline \multicolumn{6}{|c|}{$A_{\max }=m \cdot r s_{\max }+b$} \\
\hline DOY & $b$ & $m$ & $r$ & $n$ & $p$-value \\
\hline 127 & 19.34 & -0.56 & -0.34 & 5 & 0.5798 \\
\hline 176 & 32.78 & -2.12 & -0.85 & 8 & 0.0078 \\
\hline 183 & 48.75 & -6.01 & -0.92 & 11 & $<0.0001$ \\
\hline 229 & 48.69 & -7.18 & -0.81 & 11 & 0.0024 \\
\hline 253 & 38.66 & -4.03 & -0.87 & 11 & 0.0005 \\
\hline \multicolumn{6}{|c|}{$\mathrm{Tr}_{\max }=m \cdot r \mathrm{~s}_{\max }+b$} \\
\hline DOY & $b$ & $m$ & $r$ & $n$ & $p$-value \\
\hline 127 & 7.58 & -0.74 & -0.91 & 5 & 0.0238 \\
\hline 176 & 7.32 & -1.19 & -0.79 & 8 & 0.0198 \\
\hline 183 & 6.20 & -0.39 & -0.40 & 11 & 0.2252 \\
\hline 229 & 4.90 & -0.51 & -0.66 & 11 & 0.0272 \\
\hline 253 & 5.15 & -0.39 & -0.84 & 11 & 0.0006 \\
\hline \multicolumn{6}{|c|}{$\mathrm{rs}_{\max }=m \cdot \mathrm{VPD}+b$} \\
\hline DOY & $b$ & $m$ & $r$ & $n$ & $p$-value \\
\hline 127 & 9.20 & -3.15 & -0.77 & 5 & 0.1297 \\
\hline 176 & 2.63 & 0.09 & 0.02 & 8 & 0.9634 \\
\hline 183 & 0.05 & 2.76 & 0.75 & 11 & 0.0081 \\
\hline 229 & 0.61 & 1.35 & 0.60 & 11 & 0.0509 \\
\hline 253 & 1.95 & 1.59 & 0.50 & 11 & 0.1167 \\
\hline \multicolumn{6}{|c|}{ Canopy level } \\
\hline \multicolumn{6}{|c|}{$E=m \cdot \mathbf{R g}+b$} \\
\hline DOY & $b$ & $m$ & $r$ & $n$ & $p$-value \\
\hline 127 & -2.45 & 0.010 & 0.78 & 18 & 0.00011 \\
\hline 176 & -0.13 & 0.007 & 0.71 & 16 & 0.00192 \\
\hline 183 & 0.23 & 0.008 & 0.96 & 18 & $<0.0001$ \\
\hline 229 & -0.26 & 0.007 & 0.94 & 18 & $<0.0001$ \\
\hline 253 & 0.74 & 0.006 & 0.89 & 16 & $<0.0001$ \\
\hline
\end{tabular}

7165
BGD

$7,7131-7172,2010$

The influence of leaf photosynthetic efficiency and stomatal closure

A. Schickling et al.

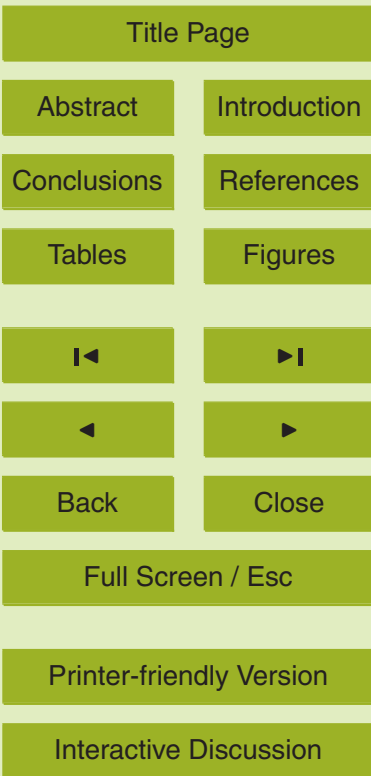


Table 2. Statistic parameters characterizing the relationship between $V P D$, ${ }_{p o t} W U E_{L}$ and $W_{C} E_{C}$, respectively. Given are the independent parameters of the single exponential decay functions $y_{0}, \alpha$ and $b$, as well as the coefficient of determination $r^{2}$ and the number of data points $n$.

\begin{tabular}{|c|c|c|c|c|c|}
\hline \multicolumn{6}{|c|}{ Leaf level } \\
\hline \multicolumn{6}{|c|}{${ }_{\text {pot }} \mathrm{WUE}_{\mathrm{L}}=y_{0}+a \cdot e^{-\frac{\mathrm{VPD}}{b}}$} \\
\hline DOY & & $\alpha$ & $b$ & $r^{2}$ & $n$ \\
\hline 127 & 3.47598 & 22.88966 & 0.41113 & 0.83792 & 5 \\
\hline 176 & 5.947 & 5558.36324 & 0.11945 & 0.76857 & 8 \\
\hline 183 & -2.06268 & 19.87179 & 1.50707 & 0.71849 & 11 \\
\hline 229 & 7.9762 & 934.76862 & 0.12185 & 0.9014 & 11 \\
\hline 253 & 2.68964 & 8.14007 & 1.55912 & 0.60842 & 11 \\
\hline \multicolumn{6}{|c|}{ Canopy level } \\
\hline \multicolumn{6}{|c|}{$\mathrm{WUE}_{\mathrm{C}}=y_{0}+a \cdot e^{-\frac{\mathrm{VPD}}{b}}$} \\
\hline DOY & $y_{0}$ & $\alpha$ & $b$ & $r^{2}$ & $n$ \\
\hline 127 & 3.99512 & 29.00188 & 0.44335 & 0.94118 & 18 \\
\hline 176 & 0.55602 & 11.42832 & 0.87504 & 0.80396 & 15 \\
\hline 183 & 2.26076 & 6.01692 & 1.01649 & 0.74316 & 18 \\
\hline 229 & 2.85883 & 9.62848 & 0.71759 & 0.88738 & 18 \\
\hline 253 & 3.61802 & 176.693 & 0.16897 & 0.87646 & 16 \\
\hline
\end{tabular}

\section{$7,7131-7172,2010$}

The influence of leaf photosynthetic efficiency and stomatal closure

A. Schickling et al.

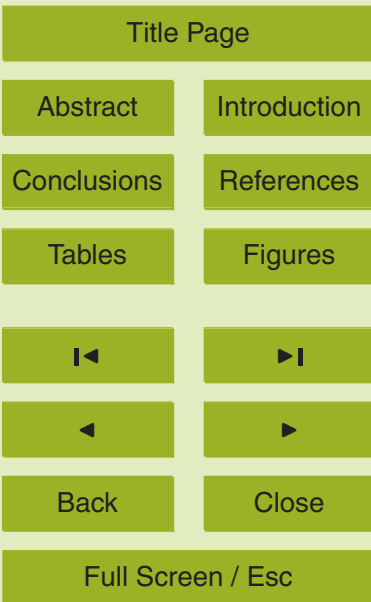

Printer-friendly Version

Interactive Discussion 


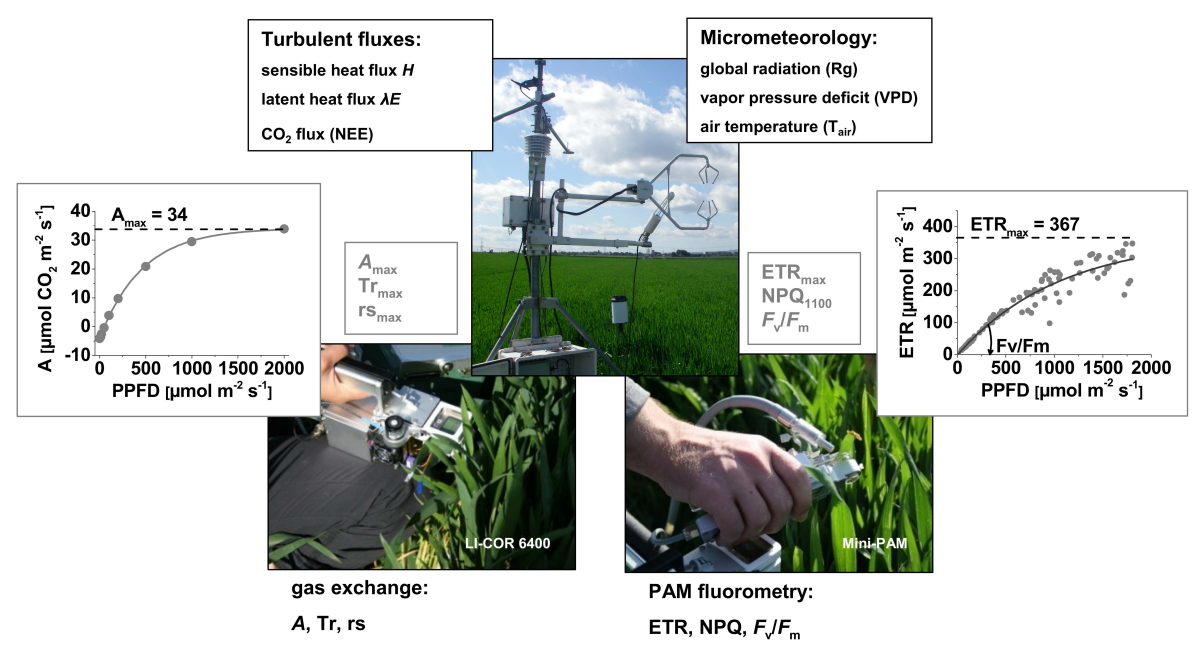

Fig. 1. Overview of the instrumentation and various measurements at different levels of the vegetation-atmosphere system. Gas exchange of single leaves was recorded to determine $\mathrm{CO}_{2}$ assimilation rate $(A)$, stomatal resistance to water vapor $(\mathrm{rS})$ and transpiration rate (Tr). Light curves allowed the estimation of maximum net photosynthetic $\mathrm{CO}_{2}$ uptake $\left(A_{\max }\right)$ and transpiration rate $\left(\mathrm{Tr}_{\max }\right)$ as well as maximum stomatal resistance $\left(\mathrm{rs}_{\max }\right)$ to characterize the potential photosynthetic performance at saturating light intensity. Apparent electron transport rate (ETR) and non-photochemical quenching (NPQ) processes were determined with PAM fluorometry. To achieve characteristic plant parameters independent of momentary light conditions, such as the maximum apparent electron transport rate $\left(E T R_{\max }\right)$ of the canopy, several hundred randomly distributed leaf measurements within the canopy were made and data were fitted using a photosynthesis model. Turbulence measurements above both canopies were used to derive sensible $(H)$ and latent $(\lambda E)$ heat flux as well as $\mathrm{CO}_{2}$ fluxes (net ecosystem exchange NEE). Additional measurements of global radiation (Rg), air temperature and water vapor pressure deficit (VPD) above the canopy describe the micrometeorological conditions during measurements.

\section{BGD}

$7,7131-7172,2010$

The influence of leaf photosynthetic efficiency and stomatal closure

A. Schickling et al.

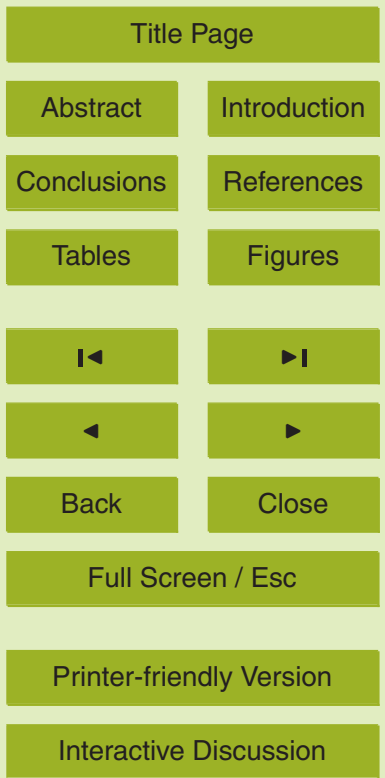




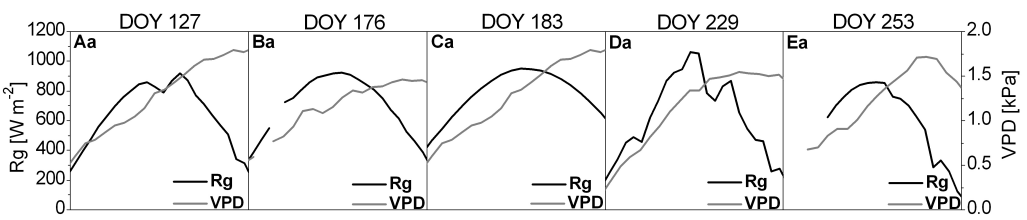

BGD

7, 7131-7172, 2010

The influence of leaf photosynthetic efficiency and stomatal closure

A. Schickling et al.
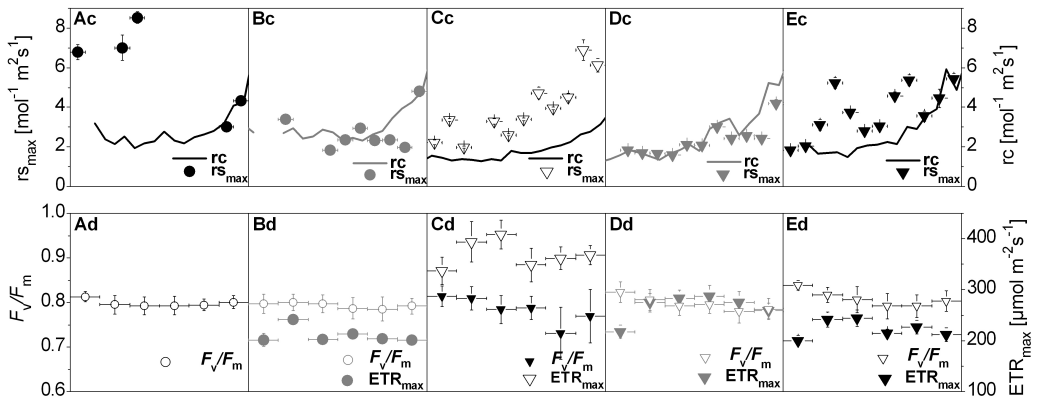

Title Page

Abstract

Introduction

Conclusions

References

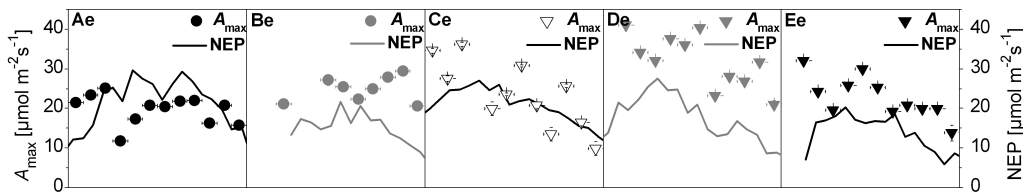

Tables

Figures

14

$>$ I

4

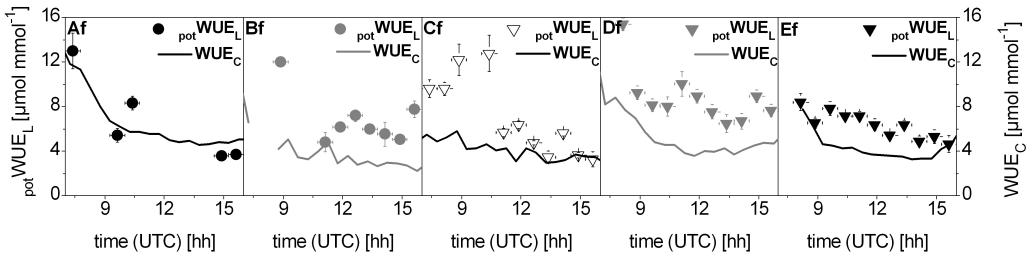

Back

Close

\section{Full Screen / Esc}

Printer-friendly Version

Interactive Discussion

Fig. 2. Caption on next page. 


\section{The influence of leaf photosynthetic efficiency and stomatal closure}

Fig. 2. Diurnal patterns of plant physiological parameters and plant-mediated exchange on two days for winter wheat (DOY 127, 176) and three days for sugar beet (DOY 183, 229, 253). Lines indicate eddy covariance measurements and symbols leaf-level measurements, respectively. Circles represent values for winter wheat and triangles sugar beet. First row: (Aa-Ea), global radiation (Rg) and vapor pressure deficit (VPD); second row: (Ab-Eb), maximum transpiration on leaf level ( $\operatorname{Tr}_{\text {max }}$ ) and evapotranspiration $(E)$ on canopy level; third row: (Ac-Ec), maximum leaf stomatal resistance $\left(\mathrm{rs}_{\max }\right)$ at light saturation and canopy resistance $(\mathrm{rc})$; forth row: (AdEd), maximum potential quantum yield of photosynthesis $\left(F_{\mathrm{v}} / F_{\mathrm{m}}\right)$ and maximum photosynthetic electron transport rate $\left(\mathrm{ETR}_{\max }\right)$; fifth row: (Ae-Ee), maximum net photosynthetic $\mathrm{CO}_{2}$ uptake rate $\left(A_{\max }\right)$ on leaf level and net ecosystem productivity (NEP) on canopy level; sixth row: (Af-Ef): potential water use efficiency on leaf level ( ${ }_{\text {pot }} W U E_{L}$ ) and water use efficiency on canopy level $\left(W_{C}\right)$. Vertical error bars: \pm standard deviation besides $E T R_{\max }, A_{\max }$ and $\operatorname{Tr}_{\max }$ uncertainty value of the fitting function; horizontal error bars: period of measurement.

\section{A. Schickling et al.}

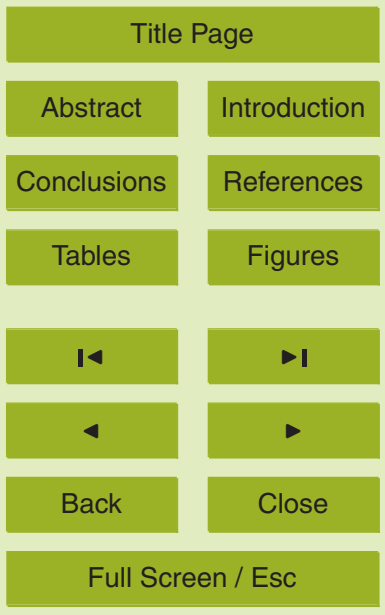

Printer-friendly Version

Interactive Discussion 


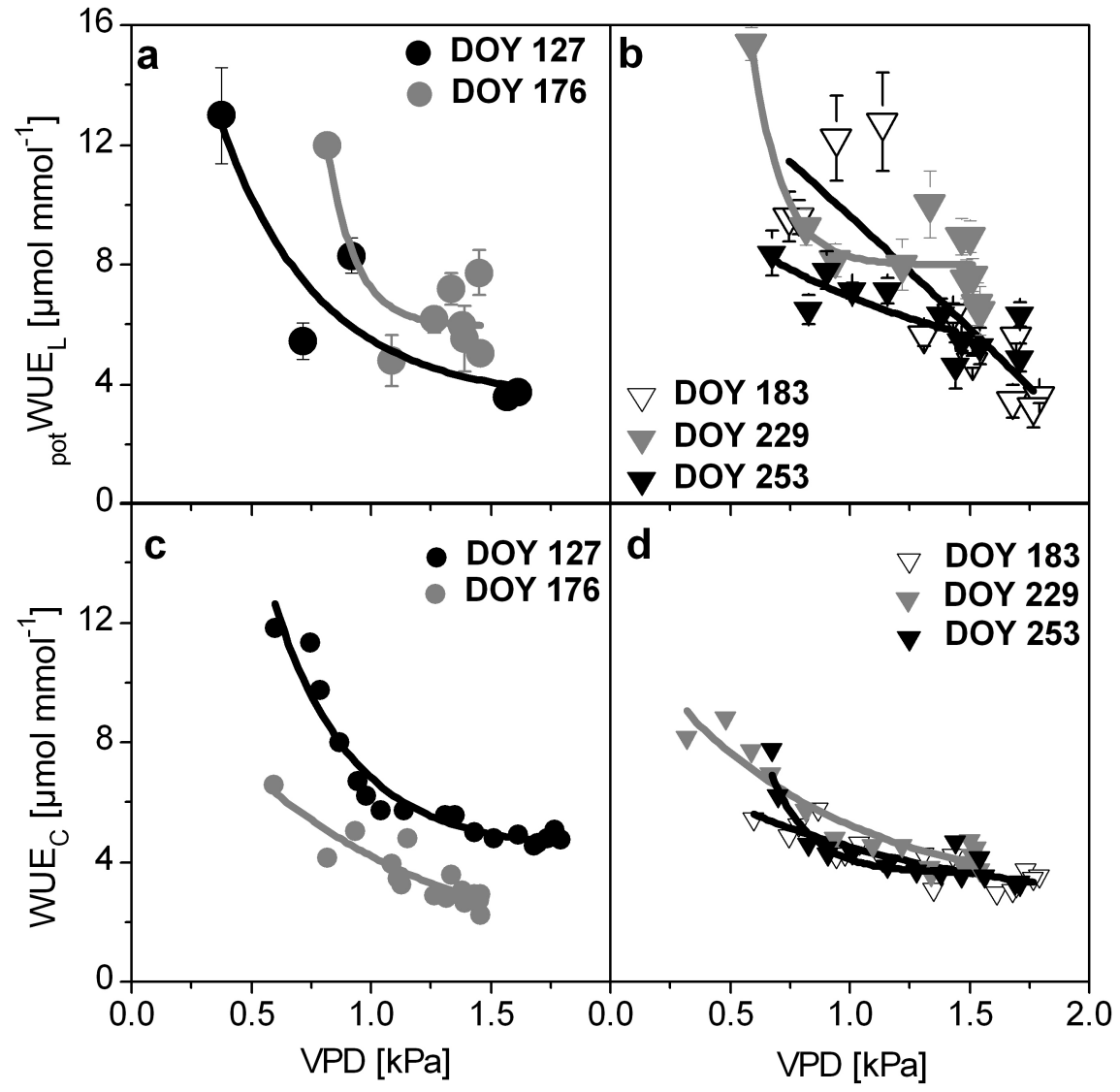

Fig. 3. (a, b) Correlation of vapor pressure deficit $(V P D)$ and ${ }_{p o t} W U E_{L}$ for wheat $(A)$ and sugar beet (a). Vertical error bars: \pm uncertainty value. (c, d) Correlation of vapor pressure deficit (VPD) and $\mathrm{WUE}_{\mathrm{C}}$ for wheat (c) and sugar beet (d). Data were fitted using a single exponential decay function (see Table 2).
BGD

$7,7131-7172,2010$

The influence of leaf photosynthetic efficiency and stomatal closure

A. Schickling et al.

Title Page

Abstract

Introduction

Conclusions

References

Tables

Figures

14

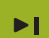

4

Back

Close

Full Screen / Esc

Printer-friendly Version

Interactive Discussion 


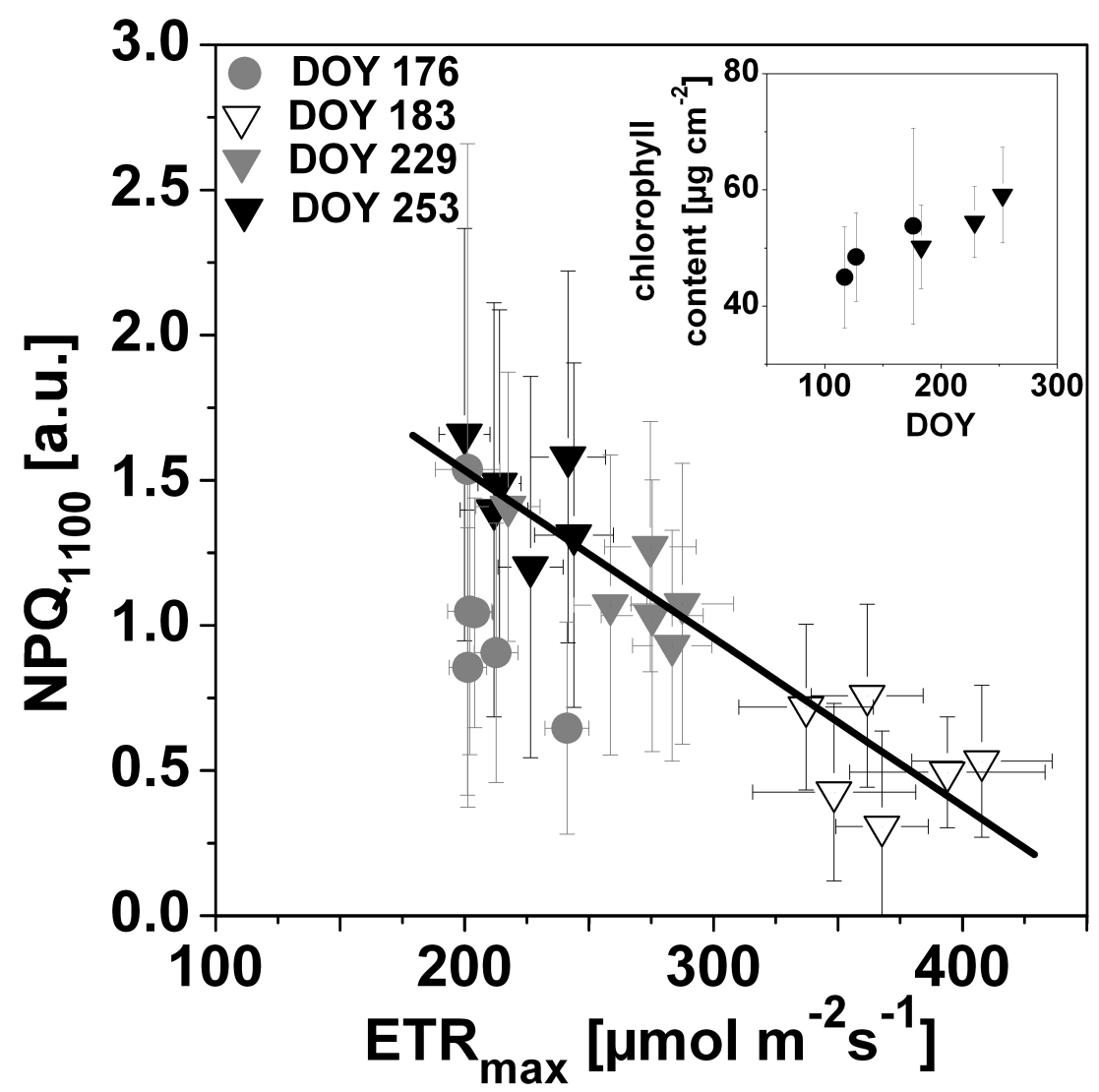

Fig. 4. Correlation of maximum electron transport rate $\left(E T R_{\max }\right)$ and non-photochemical quenching parameters $\mathrm{NPQ}_{1100}$ for winter wheat (DOY 176) and sugar beet (DOY 183, 229, 253). Thick line: linear fit to the seasonal development of sugar beet. Error bars: \pm standard deviation or uncertainty value (see Sect. 2.3.2). The insert shows the seasonal development of leaf chlorophyll content. $\mathrm{Circle=}=$ winter wheat, triangle=sugar beet.
BGD

$7,7131-7172,2010$

The influence of leaf photosynthetic efficiency and stomatal closure

A. Schickling et al.

\section{Title Page}

\section{Abstract}

Conclusions

Tables

14

4

Back
Introduction

References

Figures

- I

Close
Full Screen / Esc

Printer-friendly Version

Interactive Discussion 


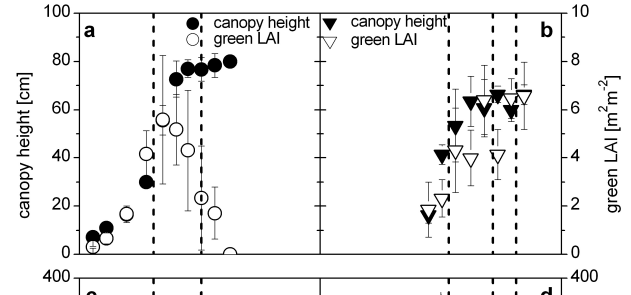

BGD

7, 7131-7172, 2010

The influence of leaf photosynthetic efficiency and stomatal closure

A. Schickling et al.

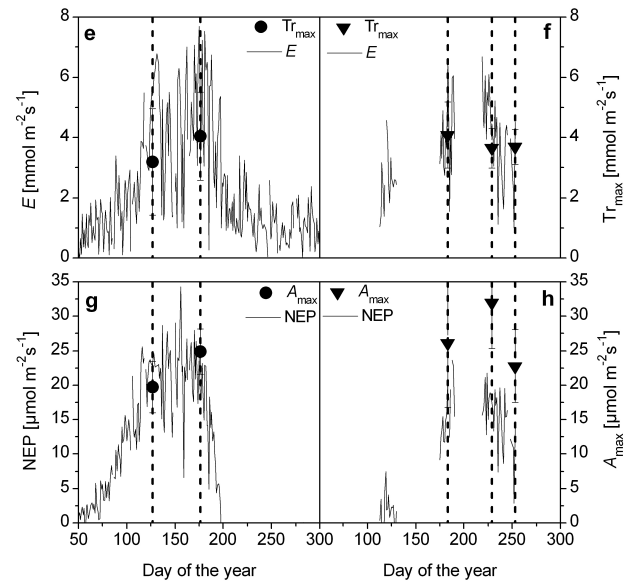

Title Page

Abstract

Introduction

Conclusions

References

Tables

Figures

14

$\rightarrow 1$

4

Back

Close

Full Screen / Esc

Fig. 5. Seasonal development of several parameters for winter wheat (left) and sugar beet (right). From top to bottom: canopy height and leaf area index (LAI) (mean \pm sd); daily means of global radiation $(\mathrm{Rg})$, evapotranspiration $(E)$ and maximum leaf transition rate $\left(\operatorname{Tr}_{\max }\right)$; net ecosystem productivity (NEP) and maximum net photosynthetic $\mathrm{CO}_{2}$ uptake $\left(A_{\max }\right)$. Dashed lines mark the five days of core measurements.

Printer-friendly Version

Interactive Discussion

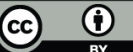

